\title{
Professional know-how and MSD prevention: conceptual and methodological reflection leading to their identification and the start of their construction
}

Savoirs professionnels et prévention des TMS : réflexions conceptuelles et méthodologiques menant à leur identification et à la genèse de leur construction Saberes profesionales y prevención de LME : reflexiones conceptuales y metodológicas que conducen a su identificación y a la génesis de su construcción Sylvie Ouellet and Nicole Vézina

\section{CpenEdition Journals}

Electronic version

URL: http://journals.openedition.org/pistes/2260

DOI: $10.4000 /$ pistes. 2260

ISSN: 1481-9384

Publisher

Les Amis de PISTES

Printed version

Date of publication: 1 November 2008

Electronic reference

Sylvie Ouellet and Nicole Vézina, « Professional know-how and MSD prevention: conceptual and methodological reflection leading to their identification and the start of their construction »,

Perspectives interdisciplinaires sur le travail et la santé [Online], 10-2 | 2008, Online since 01 November 2008, connection on 01 May 2019. URL : http://journals.openedition.org/pistes/2260 ; DOI : 10.4000/ pistes. 2260

This text was automatically generated on 1 May 2019.

\section{cc) (7)}

Pistes est mis à disposition selon les termes de la licence Creative Commons Attribution - Pas d'Utilisation Commerciale - Pas de Modification 4.0 International. 


\section{Professional know-how and MSD prevention: conceptual and methodological reflection leading to their identification and the start of their construction}

Savoirs professionnels et prévention des TMS : réflexions conceptuelles et méthodologiques menant à leur identification et à la genèse de leur construction Saberes profesionales y prevención de LME : reflexiones conceptuales y metodológicas que conducen a su identificación y a la génesis de su construcción

\section{Introduction}

The workplace has been marked by major changes over the last few decades, leading to new forms of work organization, the search for versatility in personnel, and the creation of numerous learning environments for workers (Rouilleault, H., Rochefort, T. (2005), Murray et al., 2004; Laflamme, 2002; Everaere, 1999; Dubé and Mercure, 1997; Sperandio, 1996). Manpower training has become a major issue for management, which is granting increasing importance to the know-how developed by employees (Doray and Dubar, 2004). These changes may account for the fact that the fields of occupational health and ergonomics have seen a growing interest for this concept of know-how, especially for the "preventive skills ${ }^{1[}$ " that allow workers to protect themselves. This interest is reflected in several studies that aim, on the one hand, to describe the know-how that allows workers to deal with the constraints that are encountered and protect their health (Denis et al., 2007; Chassaing, 2006; Ouellet et al., 2003; Chatigny, 2001a; Lachance, 2000; Authier, 1996; Gaudart; 1996) and, on the other, to show the usefulness of acquiring the developed 
know-how in order to create training content that favours the development of know-how in trainees or apprentices (Vézina et al., 1999). However, studying know-how presents a considerable challenge for researchers because it is very difficult to describe, in particular because of the difficulty workers have formalizing their work methods (Teiger, 1996, 1993; Daniellou and Garrigou, 1995, Reber, 1989). Two factors may account for this: 1- the development of automatic reflexes in the work being done that make several trade skills unconscious, thus freeing up the brain so that the critical situations can be planned for and anticipated (Leplat, 2005); 2- the lack of opportunities for such workers to formalize their know-how (Vézina et al., 1999). The study presented in this article aims to advance discussion on this question. Note that the study was carried out as part of a doctoral project and follows work already done by CINBIOSE researchers (Chatigny, 2001b; Vézina, 1999). The general aim of the project is to advance knowledge on the relationship between how training is organized, learning conditions, training content, and the development of new motor skills. Though work was done during the study to modify the training structure and learning conditions, this article will only deal with training content design.

2 The study was conducted at a company with a total of 350 production employees, 25 of whom clean and debone pork hams. The workers are all male and right-handed and are $41.8 \pm 7.3$ years old on average. A few years ago, work restructuring led to the tasks being broken down into individual operations. The study was done at the request of the company, which wished to obtain a training program for the deboning of meat and obtain guidelines on how to structure their training in order to prevent musculoskeletal disorders (MSDs), a major problem. The workers transform the pork hams in sequence on a mobile production line. The general pace is 18 seconds, i.e. each 18 seconds, a right or left piece of meat falls randomly onto the conveyor belt. For the purposes of this article, only deboning is being considered. It involves two sequences: the first consists in removing the bone from the animal's hip ("pelvis" sequence), and the second involves the removal of the two bones from the foot connected by a joint ("femur" sequence). Our study pertains to the latter sequence since it is the longer one and was identified by workers as being the hardest one to learn. The assembly line includes three side-by-side workstations used for the "femur" sequence. Each deboner at these stations handles one piece of meat out of three, which gives each worker 54 seconds to complete a sequence that includes the following operations: 1- positioning the piece of meat; 2- deboning the piece of meat; 3- doing the finishing of the inside piece; 4- putting the piece of meat back and; 5- sharpening the knife. Since the study deals with deboning, we are only presenting the time required for operation no. 2, "deboning the piece of meat." Eleven workers are involved in this operation since the stations are rotated on the assembly line.

\section{Theoretical framework}

3 It should first be noted that this research project in ergonomics was based on the integration of several concepts and models originating from different fields: ergonomics (Guérin et al., 2006; Chatigny, 2001; Vézina, 2001; Bourgeois et al. 2006) to describe the work, physiology (Bouisset, 2002) to discuss the stresses/strains related to the complexity of the task and motion, and neurophysiology to understand the mechanisms involved in motion control and motor skill development (Schmidt, RA., Lee TD., (2005); Berthoz, 1997; Latash, M.L., Turvey, M.T., 1996). In this article, we will be using an ergonomics-based 
approach to describe the skills and knowledge developed by the experienced workers. The overall job task will be considered while taking the individual person into account with his specific characteristics, status and views, while looking for the various influencing factors, namely the company with its operating procedures and the conditions under which the work is done, as well as by describing the task as an anticipated and fixed outcome.

As mentioned in the introduction, the study of know-how is not simple because skills are difficult to describe. In this respect, Jones and Wood (quoted by Rasse, 1991) mention that

"Their origins (they are part of the informal realm), their method of transmission (using a learning process based on demonstration and observation, where the spoken and written word is reduced to the bare minimum), their everyday nature (they are acquired through force of habit, movements repeated a thousand times and automatic reflexes) are such that skilled employees are rarely aware of them and only manage to talk about them in a very cursory manner, allusively and sparsely."

But what lies behind the concept of skill? Does wanting to describe it not assume also being able to define it? Many attempts have been made in this respect without there being any consensus as to a precise definition (Le Boterf, G. 2006; Minet, 2005; Chatigny and Vézina, 2004; Garrigou et al., 2004; Chatigny, 2001, Danis et Solar, 1998; de Montmollin, 1997; de Terssac, 1996; Stroobants, M., 1993; Pelegrin, 1991; Rasse, 1991; Chevallier, D., 1991; Chevallier, 1989). Hence, for some authors, the concept of skill refers to knowledge (general, operational, routine), to how it is used and how it is acquired (de Terssac, 1996), or to procedural knowledge expressed in the job task (de Montmollin, 1997). For others, the concept of skill corresponds to an "ability," either operational abilities that are interwoven, acquired through the work process (Barcet et al., 1983, quoted by Stroobants, 1993, p. 49), the ability to carry out mental tasks and estimate the outcome of such tasks (Pelegrin, 1991), or the ability to successfully complete a specific task through personal involvement (Deforge, 1991). However, the above authors do not clearly state how a person acquires such an "ability" to successfully complete or carry out tasks.

6 As for the notion of "preventive skills," it seems just as difficult to describe based on the few definitions found in the literature. First, note that, though not always expressed explicitly, the authors all seem to suggest that "preventive skills" consist of informal practices along the lines of safety or health protection. For instance, Cru and Dejours (1983, quoted by Garrigou et al., 2004, p. 507) see preventive know-how as a set of safetyrelated attitudes, behaviours and operating methods, while Chatigny and Vézina (2004) mention that the

"development of preventive skills does not just consist in applying individual prevention-based rules but primarily involves developing, in conjunction with a worker's environment, the worker's own preventive strategies, the best compromises that allow a balance to be maintained between oneself, others and the production system."

7 For their part, Garrigou et al. (2004) present a more detailed definition of the concept of preventive skills by providing examples of what can also be called strategies developed by workers. They state that these skills

"can pertain to different aspects, both individually and collectively: the preparation of high-risk tasks; the way a task is carried out; staying focused and vigilant; anticipating unforeseen situations or variations in work situations; demonstrations or 'tricks' for perceiving, feeling or managing stress or agitation; checking and 
taking stock of the tasks being carried out; the coordination of tasks involving different players; monitoring the difficulties encountered by other workers, such as new hires; the transmission, within the group, of stories of incidents that support vigilance."

But can all the strategies used by workers aimed at health protection be thought of as necessarily efficient in this respect? If not, are preventive skills still involved? How are preventive skills involved? Is it the target objective of protecting oneself or their efficiency? According to Vidal-Gomel (2002),

"preventive skills are either functionally as efficient as a safety rule, if used in its place, or complement a safety rule."

However, when repetitive manual work is involved with a high MSD risk that is caused by multiple factors, can we talk about preventive skills only in terms of how efficient a worker is in protecting himself? Would it not be more appropriate to consider the notion of "compromise," which reflects what a worker considers to be the most efficient in a given situation at a given point in time?

Consequently, despite the fact that more detailed definitions of the concept of preventive skills exist, they may still not be precise enough to determine exactly how to orient our methodology when attempting to document skills in general and preventive skills in particular. As a result, this study seeks to delve further in the discussion by proposing a theoretical framework and methodology aimed at identifying the preventive skills developed by workers. This article thus aims to: 1 - propose a study of the concepts of knowledge, skills and preventive skills; 2- show how different methods are used to identify the skills of experienced workers; 3- determine the skills developed by a group of experienced workers to protect themselves and; 4- verbalize the different types of knowledge that have been developed and applied in the course of implementing the above skills. A second article will appear in a later issue that will consist in determining whether the knowledge in question has been transmitted to trainees by two experienced workers who are also trainers.

11 A study of the skills developed by workers thus requires that the definition of the concept, which is still vague despite the fact that it has been widely used in the literature on ergonomics and other fields, be first examined. After reviewing the different definitions found in the literature, our study has led us to propose a theoretical framework (Figure 1) where a skill is seen as the outcome of the application of knowledge acquired and developed a priori that is continually validated and built-up through practice (middle circle). The concept of "skill" is defined as "an individual's ability to apply knowledge in his/her work that allows a goal to be attained." With experience and practice, the individual develops a number of skills that allow him/her to meet production-related requirements and/or protect his/her health. These are the skills that allow an experienced worker to create some manoeuvrability. Manoeuvrability is defined by Durand et al. (2008) as the individual's adjustment possibilities while working. It is the result of the interaction between work-related requirements and the individual's capacities. As shown in Figure 1, skills are expressed at work through what is done, which makes us present them through action verbs. If we take the example of the sharpening of a knife (Vézina et al., 1999), we would describe a skill as "sharpening a knife by maintaining the blade at the right angle on the sharpening stone." Having a skill thus requires knowledge of how something is done (Theureau, 1991, p. 43). As a result, to be able to identify professional skills, it is essential to analyze the job task and more 
specifically what is done during the task. This approach is in line with the one proposed in professional didactics that focuses on questioning what practitioners do (Pastré, 2004). Note that the meaning of the concept of "movement" or "motion" that is used here is the one presented by Bourgeois et al. (2006) that requires that actions be well-considered, chosen and suited to the situation, and resulting from a compromise between the objectives, the task, the work methods and the individual characteristics of the person performing them, thus describing what the person is doing. This concept of motion takes into account not only characteristics related to movement (e.g. range, strength, speed, acceleration) but also those that are psychological (e.g. desire, intent, emotion) and social (e.g. handshake, lending a hand) in nature.

In ergonomics studies, a skill used as a protective measure is usually referred to as a "preventive skill." We will use this term when referring to "the ability of an individual person, who is exercising care, to apply a set of skills in a job aimed at protecting his/her health and that of others." We consider that the skill is preventive in nature when a worker has expressed an intent to protect him/herself or others. Note that in this study, health is defined as a

state of complete physical, mental and social well-being, and not only as the lack of illness or disability (OMS, 1948).

Moreover, what does such knowledge manifested through skills consist of? Figure 1 shows our view of the question, which was developed based on the methodological need to identify the elements determined at the time we examined the job task and the training of the experienced workers taking part in the study.

Figure 1. Flow chart describing the concept of know-how

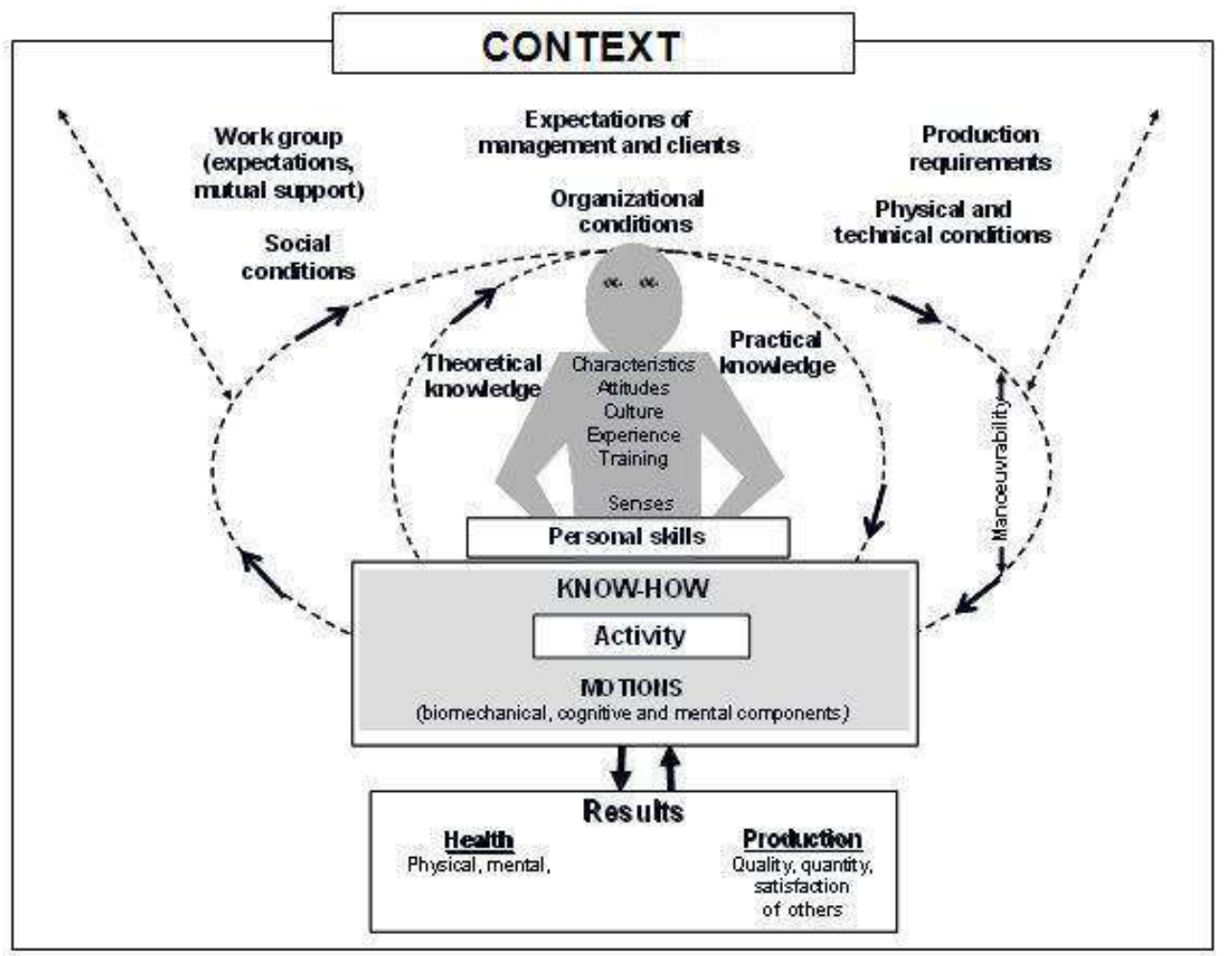

14 It is important to point out that the theoretical framework and typology that were developed have been based more on field work than a combination of the various theories 
found in other fields, in particular professional didactics. Though these theories are very interesting, they largely pertain to the concept of "competence," for which there are different definitions. In addition, there are various interpretations and it is sometimes difficult to fully understand the relationship between the concept of "competence" and that of "skill," which merits a more in-depth analysis than what is being given in this article.

Hence, we are proposing a typology of applied skills that includes theoretical and practical know-how, with the concept of "knowledge" being considered as something acquired through training and/or experience. In addition to these two types of knowledge there are personal skills which, like know-how, result from the relationship between a set of personal factors and for which we are using the definition given by Ketele (quoted by Barbier and Galatanu, 2004, p. 59), which presents personal skills as

"activities through which a person not only shows how he understands himself

("self-image"), others, events and life in general, but also how he acts and reacts."

We consider that a person will develop such behavioural skills through experience using inner resources (characteristics and memory of past experiences) as well as what he/she will be able to receive and perceive from the collective realm. Just like know-how, behavioural skills cannot be transmitted. However, instructions on the principles or values to be applied in completing the task can be, such as the principle of "being attentive " or tricks on improving concentration. Based on what is transmitted, the trainee will attempt to develop such a capacity for attentiveness by trying to integrate the tricks based on his/her characteristics, abilities, past experience, and perception of the level of attention required. The objective in this study is not to describe the knowledge required to develop the behavioural skills of a deboner, since we consider that this aspect is beyond the role and field of competence of ergonomists. However, we cannot disregard this personal component in our model since, on the one hand, the ergonomic approach focuses on the person carrying out the work with his/her past experiences and characteristics and, on the other, because worker-trainers verbalize principles associated with behaviours when deboning.

17 To make it easier to understand our model and the results that will be presented further on, we are presenting the meanings given to these different types of knowledge. First, note that theoretical knowledge is specialized knowledge related to a specific field that is basically acquired through formal or informal training. It therefore consists of knowledge that the trainer will be transmitting to trainees during a training session. It can be found in written form in manuals and can be supplemented through observation and the understanding of a formalized practice. "Practical knowledge," for its part, consists of knowledge developed in practice such as tricks, cues, strategies, techniques, procedures and possible solutions. Among experienced workers, such knowledge results from comparing and making associations between different contextual elements that improve their judgment and help them decide which actions are the most appropriate based on the circumstances. Over time, "practical knowledge" is no longer necessarily conscious and becomes difficult to verbalize. Such knowledge is obviously limited among trainees. It serves to complement and relativize "theoretical knowledge" and can even become "theoretical knowledge" once it has been formalized and integrated in training that will be provided to trainees. In the context of analyzing the work done by experienced workers in view of developing training material, the objective is thus to have the latter verbalize their practical knowledge (developed in practice) so that it can be transmitted to the next 
generation of workers (thus becoming theoretical knowledge). Naturally, trainees will always have to develop their own practical knowledge since they will need to put their theoretical knowledge into practice and tailor it their personal characteristics.

For instance, when preparing the training for knife sharpening (Vézina et al., 1999), the identification of skills through the analysis of the task revealed that the experienced workers would keep the wrist of the hand holding the knife very straight while the blade would be applied against the sharpening steel (elongated file). If this new theoretical framework is applied to this example, "keeping the wrist straight" is knowledge that is developed in practice, namely, unconscious practical knowledge that is made conscious through the analysis of the skills and that has subsequently become theoretical knowledge part of training. However, the trainee must still put this theoretical knowledge into practice (learn how to position himself so that his wrist is kept straight) and develop practical knowledge so that it can be applied during work and have it become part of his set of skills.

In Figure 1, we also wanted to show by the middle circle that skills are developed by building on all the knowledge used in the task. For instance, each test and each cycle of work that is completed allows the worker to see the results, to discover new cues and solutions enabling him to build on the practical knowledge and, as a result, his skills. A skill does not depend solely on the amount of knowledge a person has but mainly on his ability to integrate and organize knowledge of oneself and of the context (e.g. technical, organizational and social conditions) in which the work is being done. In this respect, Chevallier quotes Détienne and Vernant (1974, p. 302):

"Skills are also found in specific attitudes and mental abilities such as the capacity to predict the reactions of matter, the ability for conjecture, characteristic of the hybrid analyzed by hellenists Marcel Détienne and Jean-Pierre Vernant, which allows one to see both in front and behind simultaneously, i.e. to first experience the past to anticipate what will occur in the future, as well as bring the future of past events closer together" (Chevallier 1991, p. 5).

19 Furthermore, all of a person's senses are involved in a skill (Figure 1). The perceptualmotor skills of an experienced worker allow him to correct, adjust and choose the right movements to make while the task is being carried out. In this regard, Bril and Roux (2002) mentioned that expertise-related characteristics are not found in terms of the succession of operations carried out to attain an overall goal but rather in relation to the level of basic movements and their sequence (technical aspect) that are determining factors of a know-how that is characterized, according to the authors, by flexibility and adaptability, minimal energy expenditure, perception and use of information. With respect to perception, we are using the vision developed by Berthoz (1997) on how to approach a study of the senses, meaning that senses should not be seen only as sources of hypotheses but rather as validators of hypotheses that the brain is presenting to the world. A skill thus implies that the person "knows how to observe," "has a sense of touch," "knows how to listen," "knows how to smell," and "knows how to taste," which implies the existence of cues. For instance, to have a sense of touch, a worker seeking to develop a skill must know what there is to feel, i.e. be aware of the cues. Hence, still in the context of drawing up a training curriculum based on the skills of experienced workers, it is important to be able to identify the cues that the latter have developed in practice (practical knowledge). We will therefore be trying to determine what a worker is attempting to check when looking in a direction or touching an object. This presents a considerable challenge since it is not always easy for an experienced worker to express his movement-based intentions, on the one hand because he is no longer "consciously 
aware" of them over time and, on the other, because he has not necessarily had the opportunity in the past of verbalizing his intentions.

The model presented in Figure 1 served as a basis for the methodology that was developed in order to validate our hypotheses. It should also be mentioned that several elements involved in the analysis of the activity proposed in the methodology were based on work already done in this area by the research team (Vézina et al., 2002; Chatigny, 2001; Ouellet and Vézina, 2001; Ouellet, 2000; Vézina et al. 1999; Chatigny and Vézina, 1992, 1994; Chatigny 1993). With this study, we are trying to help prevent musculoskeletal disorders by preparing a training program. Given that the skill-related sensorimotor component requires the use of different sensory modes and the use of a variety of informal information that allows workers to correct and choose the best movement, our hypothesis is that it is necessary to do an in-depth analysis of the work-related movements to verbalize the creation of these regulations. We also believe that with a view to designing training content, a description of the skills of experienced workers should lead to theoretical and practical knowledge in writing that has been applied to develop such skills since this knowledge is what will be transmitted during training.

\section{Methodology: Understanding what is being done in order to identify the skills of experienced workers}

\subsection{Selection of experienced workers}

21 At the start of the project, six experienced workers recognized by their peers for their skills were selected. Two of them were also deboning trainers. Table 1 lists the characteristics of the experienced workers who took part in the study. As the table shows, the six workers, all of whom are right-handed, are aged 34 to 54 (average age of $44 \pm 7.9$ years), with 5 to 25 years of experience at the deboning station with the company (11 \pm 7.7 years on average). Note that four of the workers (\#2, \#4, \#5 and \#6) have held the same type of position for over 10 years in other companies in the food industry.

Table 1. Characteristics of the experienced workers

\begin{tabular}{|l|l|l|l|l|l|l|}
\hline $\begin{array}{l}\text { No. of } \\
\text { workers }\end{array}$ & Age & Height & $\begin{array}{l}\text { Dominant } \\
\text { hand }\end{array}$ & $\begin{array}{l}\text { Years in } \\
\text { the plant }\end{array}$ & $\begin{array}{l}\text { Deboning } \\
\text { experience }\end{array}$ & $\begin{array}{l}\text { Other jobs in the } \\
\text { meat industry }\end{array}$ \\
\hline$\# 1^{*}$ & 34 & $\begin{array}{l}1 \mathrm{~m} 73 \quad 5^{\prime} \\
8^{\prime \prime}\end{array}$ & Right & 12 years & 8 years & No \\
\hline$\# 2^{*}$ & 42 & $\begin{array}{l}1 \mathrm{~m} 68 \\
\left(5^{\prime} 6^{\prime \prime}\right)\end{array}$ & Right & 6.5 years & 6.5 years & $\begin{array}{l}\text { Slaughtering/ } \\
\text { deboning } \\
20 \text { years }\end{array}$ \\
\hline \# & 36 & $\begin{array}{l}1 \mathrm{~m} 80 \\
\left(5^{\prime} 11^{\prime \prime}\right)\end{array}$ & Right & 18 years & 15 years & No \\
\hline 44 & $\begin{array}{l}1 \mathrm{~m} 80 \\
\left(5^{\prime} 11^{\prime \prime}\right)\end{array}$ & Right & 10 years & 5 years & Butcher, 22-23 years \\
\hline
\end{tabular}




\begin{tabular}{|l|l|l|l|l|l|l|}
\hline \#5 & 47 & $\begin{array}{l}1 \mathrm{~m} 75 \\
\left(5^{\prime} 9 \prime\right)\end{array}$ & Right & 6.5 years & 6.5 years & Deboning, 13 years \\
\hline \#6 & 54 & $\begin{array}{l}1 \mathrm{~m} 73 \\
\left(5^{\prime} 8^{\prime \prime}\right)\end{array}$ & Right & 25 years & 25 years & Butcher, 13 years \\
\hline
\end{tabular}

*Deboning worker-trainers

\subsection{One-on-one interviews to learn about the work involved}

Subsequently, to learn about the work involved in the "femur" sequence, the difficulties encountered and the discomfort that was experienced, we met with each of the six workers individually in a semi-controlled interview lasting 60 minutes. At the time of the interview, none of the workers mentioned having to miss work because of a musculoskeletal injury associated with the deboning station. However, one of the workers mentioned having to miss work from time to time due to acute arthritic pain in his right heel. A consent form outlining the study objectives and stages was signed by all the workers who took part in the study. The six participants were allowed to withdraw from the study at any time.

\subsection{Observations at the workstation}

We observed the workstation over the course of two days to familiarize ourselves with the work organization, the steps involved in the task, and the various factors that could influence the diversity of the operating methods. Note also that there was informal verbalization during the observations. The verbalization could be spontaneous on the part of the workers or incited by the observer. In order to provide a detailed description of the operating methods and the movements made during each step of the work, we videotaped the "femur" sequence at the workstations over another two-day period in order to obtain two 30-minute recordings per worker.

\subsection{In-depth analysis of professional movements}

Before doing a systematic analysis of the work practices, we viewed the videotaped sequences in order to characterize the workers' operating methods and identify the variables that were used for the systematic analysis. Next, the Actogram software program was used to observe the work being done and to obtain data logs (Kerguelen, 2003); the software is designed to process chronological observations using digital video sequences that can be analyzed in slow motion. For the in-depth analysis of the movements, based on the video recordings, we chose 10 consecutive incident-free cycles that allowed five cycles to obtained with the right piece of meat, and five cycles with the left piece. The following was considered in the analysis: 1- temporal organization of the task (duration: cycle, inter-cycle, deboning/finishing, waiting, communication, knife sharpening, other); 2- the order in which the steps were followed; 3- the frequency of certain actions that appeared to determine the effort being exerted and the cycle time (positions the piece, puts back the piece, moves the piece); 4- the position of the piece of meat in relation to the worker (distance from the piece and position of the parts in 
relation to the worker); 5- types of grips on the knife based on the step (full-hand grip, index finger on the back of the blade, thumb on the back of the blade and low grip) and; 6- the amount of time during which each grip was used. As for the motions that were done, our analysis involved different observable elements such as: 1- direction, angle, number and length of knife strokes; 2- the articular range of certain movements of the shoulder, elbow and wrist, assessed qualitatively, and; 3- the parts of the bone (zones) where the knife thrusts are found. It is important to mention that even though the incident-free cycles were not considered for the motion analysis, the incidents were logged and discussed at meetings aimed at identifying the work method influencing factors. In addition, one section is found in the training curriculum to explain the impact of the incidents (e.g. variability of the raw materials and associated consequences) and the ways used to deal with them. The discussions on these incidents also led to recommendations in some cases. For the purposes of this article, only the results related to the average deboning time, number of knife strokes, average number of times the piece of meat was moved, and percentage of time the different types of grips were used will be presented.

\subsection{Clarifying the work practices through one-on-one interviews}

25 To document the strategies used, we held individual self-assessment meetings lasting 2.5 hours with each worker to validate the observation results that were obtained and identify the influencing factors for the elements in the methods. To do so, an interview framework was set up to favour clarifications on: 1- the steps of the task to be done; 2the different operating methods; 3 - the sensory modes that were applied; 4- the quality of the work achieved and expected and; 5- the raw materials being processed. During the meeting (which was recorded), each worker was first asked to observe himself on a videotape and make comments. One of the six workers was unavailable because he was on extended sick leave. The meeting also served to document the cognitive component of the motions that were made (Bourgeois and Hubault, 2005) by documenting the workers' intentions as well as by identifying the sensory information that was gathered to anticipate the difficulties and to correct, adjust and choose the best motion to be done during each step of the task. To favour clarification of the sensory information that was used, we prepared questions specifically on this aspect, such as: 1- Are there aspects you are looking at when the ham arrives at the "femur" workstation? If so, what are they and what information do they provide you with?; 2- Do you use visual and/or tactile cues that allow you to determine where to place your knife to trace the "inside" piece? If so, what are your cues? (Indicate them on the photographs); 3- When you remove the bone, what gives you an indication that your knife is entering at the right spot?; 4- What are you looking at when you remove the bone?; 5- Are there any cues that indicate whether the knife's blade has penetrated the meat, either correctly or not, to remove the bone? If so, what are they? The data obtained at these meetings was processed by listening to the audio recordings and based on the analysis of the notes that were taken at the meetings.

\subsection{A group meeting to discuss the knowledge to be transmitted}

To be able to respond to the company's request regarding the development of a training program, we needed to have a consensus within the group of workers regarding what elements were to be included in the "femur" sequence. We thus held two days of group 
meetings that were recorded and videotaped for a total of 14.5 hours. However, for the purposes of this article, only the data gathered during the first day will be presented since they specifically deal with the work methods, whereas the discussions on the second day mainly involved how the training was structured. At this meeting, the analysis results and the elements likely to be found in a training manual were presented via illustrations using transparencies, which facilitated the workers' understanding and expression of knowledge. Topics of discussion included the components of the various work methods and the cues that were used to facilitate the work. To make it easier for them to verbalize their knowledge, the workers were asked to write or draw on the transparencies to explain the method they used or their viewpoint. It is important to note that the objective was not to recommend work methods but rather to obtain a consensus within the group on the advantages and disadvantages found in each work method that was described in terms of product quality and health protection by systematically contrasting them. To bolster discussion, we organized a 60-minute test period in the production room during which time the workers demonstrated their work methods, tried out the other methods, and gave their opinions on the methods. Naturally, to incite the workers to verbalize their knowledge and demonstrate their skills, it was important to establish the procedures at the start of the meeting in order to create an atmosphere conducive to discussion where the workers would feel comfortable expressing themselves without any fear of being judged.

\section{Results}

In this section, we will be presenting the results in three parts. We will begin with the results related to the task that was carried out and the in-depth description of the workers' motions, after which we will present the preventive skills arising from this gestural analysis. To conclude, we will describe the knowledge that comes into play in the skills identified in the previous stage.

\subsection{The deboning task in the "femur" sequence: repetitive complexity}

operations are part of a work cycle: 1- position the piece of meat; 2- remove the bone from the piece of meat; 3- open and finish the "inside" part of the piece; 4- throw the bone onto the conveyor belt above; 5- put the piece back. Figure 2 shows the specific steps carried out for the operation entitled "remove the bone from the piece of meat." As can be seen, the first step consists in tracing the "inside" of the piece. Tracing must be done first, otherwise the other steps cannot be completed. 
Figure 2. Steps carried out to remove the bone from the piece of meat during the "femur" sequence

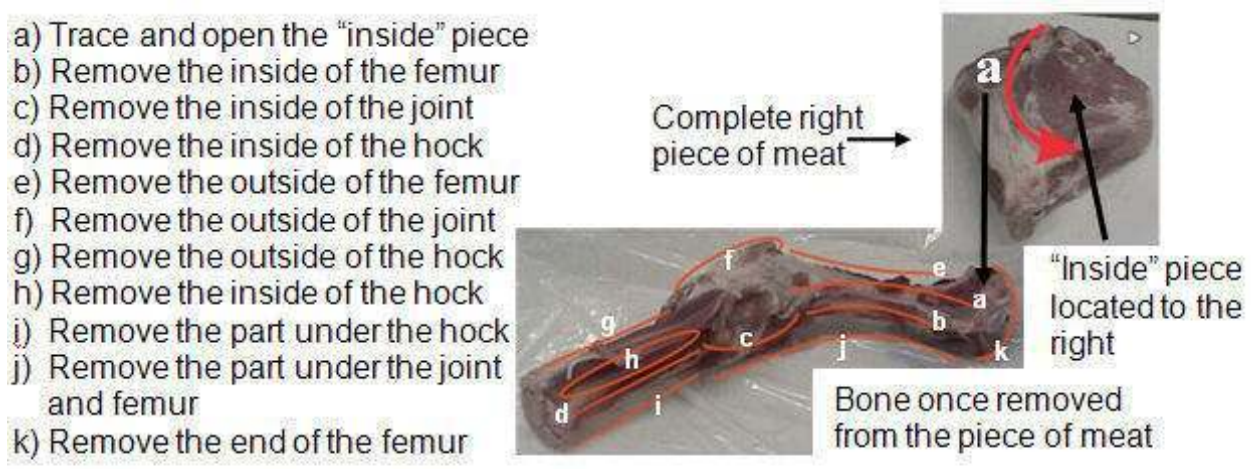

Figure 2: Steps carried out to remove the bone from the piece of meat during the "femur" sequence

29 However, the time when the "inside" piece is opened up can vary from one worker to another. This step consists in removing part of the piece of meat ("inside" piece) and laying it down on the conveyor. Some workers will open the "inside" piece at the beginning of the sequence for the right piece and at the end of the sequence for the left piece because of the order of arrival of this part of the piece of meat because of the direction of the mobile conveyor (Figures 3 and 4 ).

Figure 3. Layout of the pieces of meat in relation to the worker when the conveyor is moving left to right

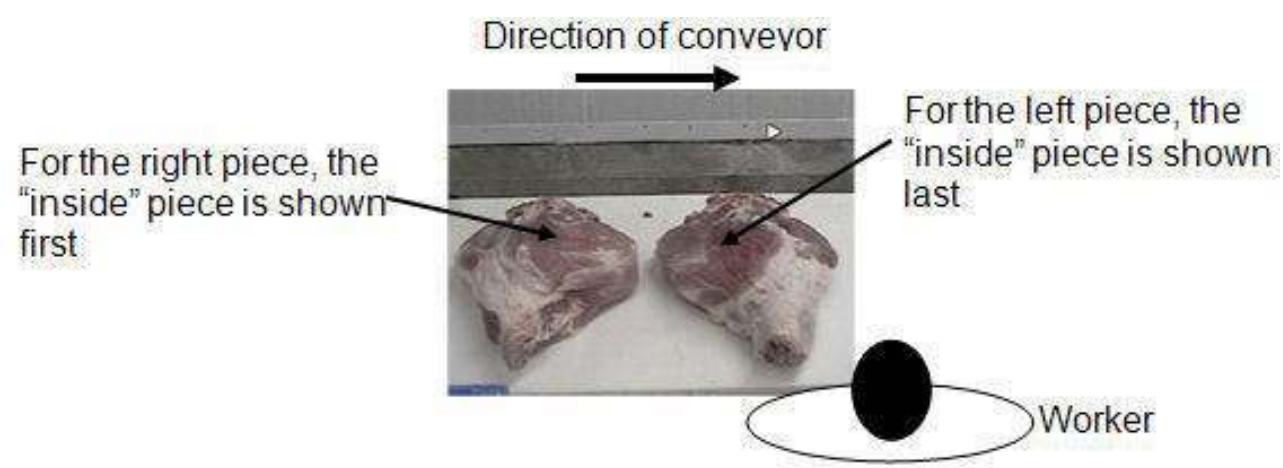

Other workers always open the "inside" piece of meat at the start of the sequence. Another difference to mention in the order of the steps is that the inside part of the bone $(b, c, d)$ is always removed before the outside part $(e, f, g)$. However, for the inside of the hock (h), four workers out of six will do this step before step "e," one worker will do this step after step " $g$ " for the right piece and before step "e" for the left piece, while the sixth worker will always do this step (h) after step "g." Therefore, it can be noted that despite the short duration of the work cycle, the fact of doing an in-depth analysis of the sequence of steps shows fairly considerable variability in the chosen order of steps. We also noted that the characteristics of the piece in relation to the conditions under which the work is performed (mobile surface and conveyor direction) have a substantial influence on the work methods. 
Figure 4. Photograph showing the removal of the outside of the bone

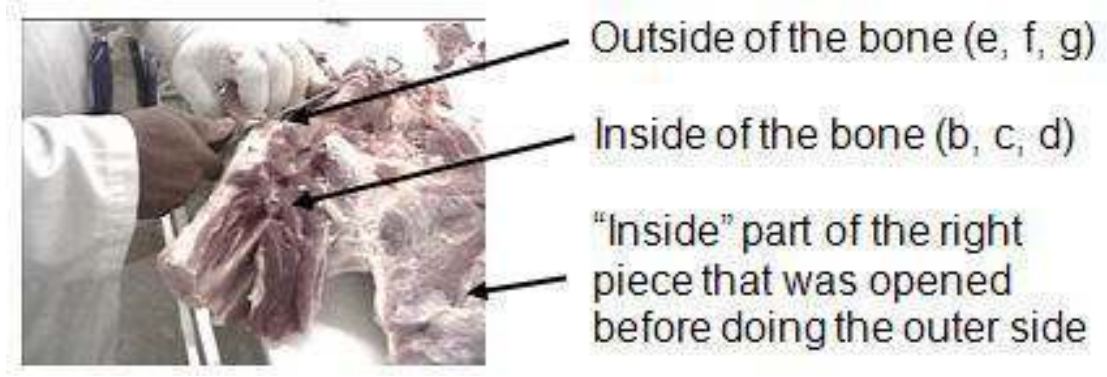

\subsubsection{Planning the work to balance time, quality and health}

Figures 5 and 6 show the relationship between the average time taken to "remove the bone from the piece of meat," the average number of knife strokes used to remove the bone, and the average number of times the piece of meat is moved. By "moving the meat" we mean "a change in position made on the conveyor without lifting the piece." The first observation is that the average time used to remove the bone from the piece of meat ranged from $21.6 \pm 2.7$ to $24.9 \pm 1.8$ seconds for the right piece and $25.6 \pm 1.6$ to $17.0 \pm 1.8$ seconds for the left piece. Note that we are not referring to the cycle time but the time taken to remove the bone from the piece. Note that the two workers (\#2,\#3) with a lower average number of knife strokes with 12 to 13 strokes (right and left) are among those with the lowest average bone removal time. In fact, these two workers recorded an average removal time of $21.6 \pm 2.7$ ( $\# 2$ ) and $23.1 \pm 1.6$ seconds (\#3) for the right piece and of $20 \pm 0.8$ and $17 \pm 1.8$ seconds, respectively, for the left piece. The worker with the longest average removal time (\#1), with $24.9 \pm 1.8$ seconds (right) and $25.6 \pm 1.6$ seconds (left), is also the one who used the most knife strokes, with an average of 16.8 (right) and 17.4 strokes (left). Note that workers \#1 and \#2 are the company's two trainers. The objective involved in presenting the data is not to determine whether there is a significant difference between the workers or between the right and left pieces, but rather to determine the extent of the variability found between one worker and another or one piece to another, while asking what impact the variability may have on the musculoskeletal effort at the end of a day. For instance, if we look at the number of knife strokes used, we note that those with the least number of knife strokes had 12 (workers \#2 and \#3), whereas those with the most had close to 17 (worker \#1). 
Figure 5. Relationship between the average bone removal time (sec.), average number of knife strokes and average number of times the piece was moved during bone removal in the right piece of meat

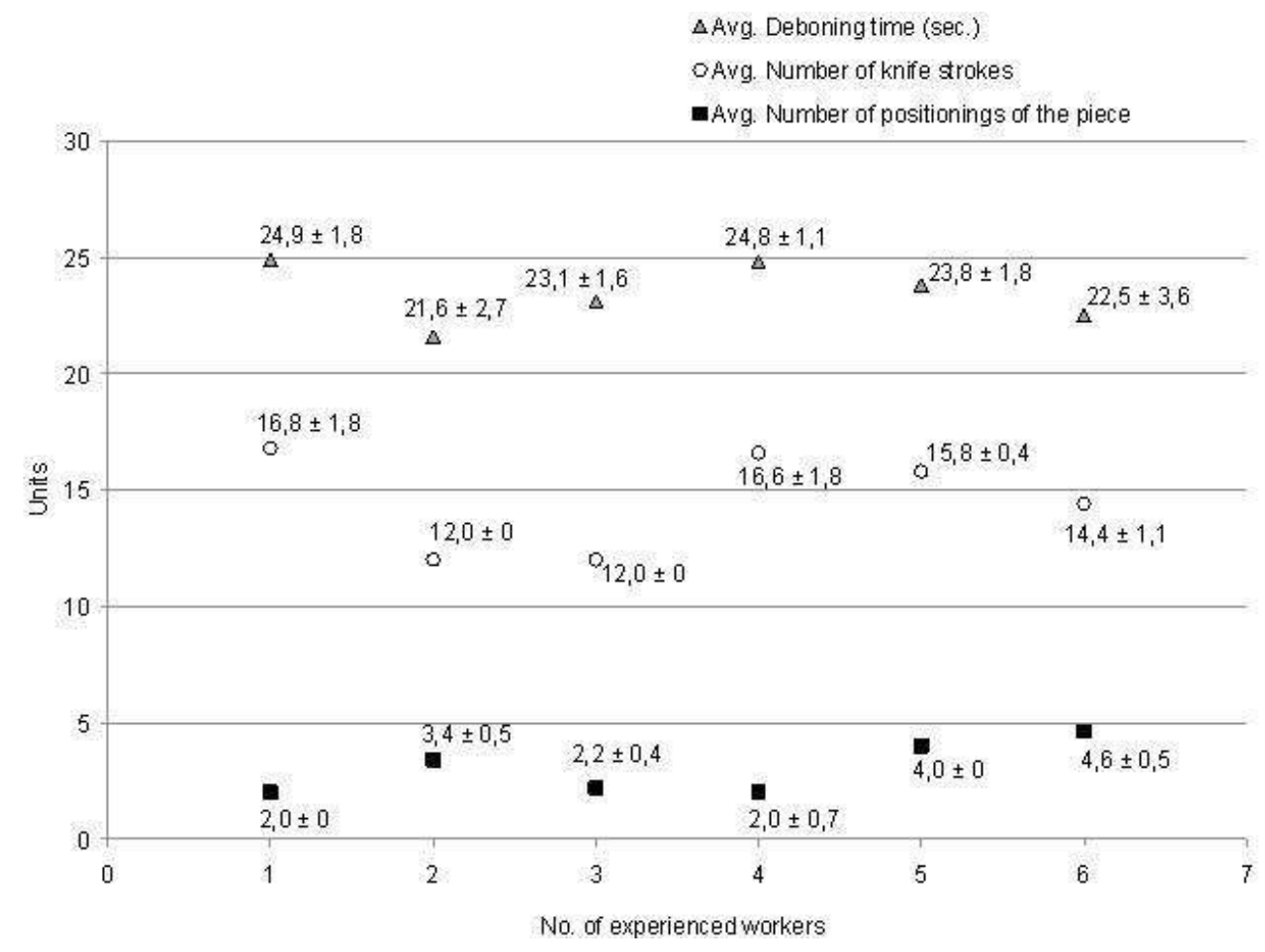

In fact, such a difference for repetitive work, with a scheduled pace of 54 seconds per piece of meat (18 seconds every three pieces) for this sequence results in worker \#1 using 2,475 knife strokes more than workers \#2 and \#3 if he were to work all day on the "femur" sequence, which represents a very significant additional effort. Even a single additional knife stroke represents an extra 495 strokes at the end of a work day, which is far from being negligible if one considers the effort that may be given, for instance, when the knife is dull and the postures used at each stroke depending on the operating methods, such as wrist deviations. There was consensus among the group of workers that the possible influencing factors for the number of knife strokes are the knife's cutting quality, the work method, and the degree of precision attained in the work. During the group meetings, the workers mentioned that it is important to limit the number of knife strokes made to decrease the workload and lost time. The demonstrations made by the workers at the meetings showed that no more than 12 to 14 knife strokes are needed to remove the bone while observing the quality criteria which consist in leaving as little meat as possible on the bone and no tearing on the piece of meat. 
Figure 6. Relationship between the average bone removal time (sec.), average number of knife strokes, and average number of times the piece was moved during the removal of the bone in the left piece of meat

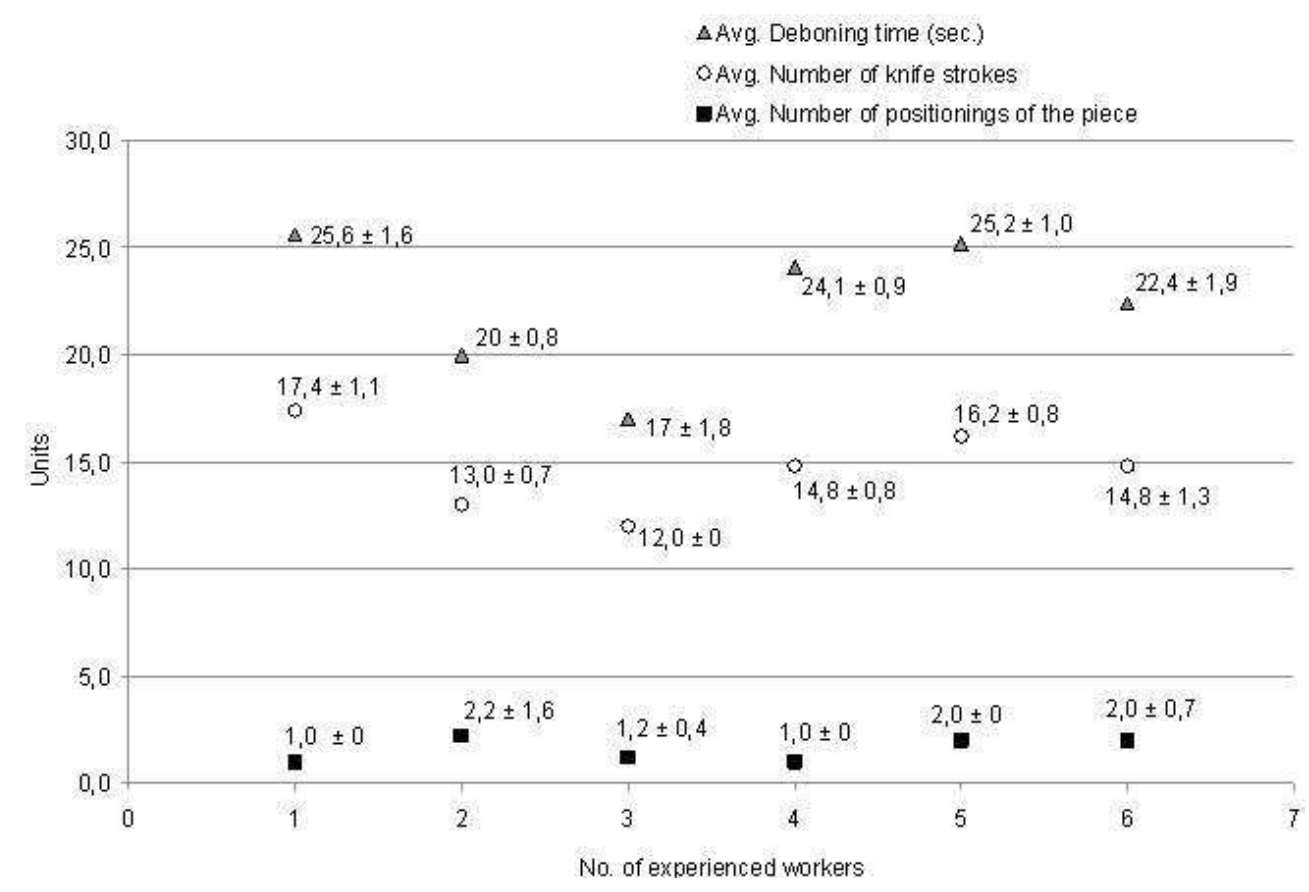

Moreover, it is also interesting to note that on average, the workers move the left piece of meat (Figure 6, 1.6 \pm 0.9 ) less than the right piece (Figure 5, $3.0 \pm 1.1$ ). We also noted that workers \#2 and \#3, who use very few knife strokes, are not necessarily those who move the piece of meat the least, with an average of $3.4 \pm 0.5$ and $2.2 \pm 0.4$, respectively, for the right piece, and $2.2 \pm 1.6$ and $1.2 \pm 0.4$ for the left piece. Furthermore, it is difficult to see a clear correlation between the number of times the piece of meat is moved and the number of knife strokes. This result may be an indication of the compromises needed to find a combination of elements that make up the work methods so that production requirements can be met while protecting health as much as possible. In this respect, the workers mentioned at the self-assessment meeting that a compromise had to be made between not moving the piece of meat too much in order to decrease the effort required and that of moving it a little so as to be more comfortable when making knife strokes. We can therefore assume that a given prevention principle, such as "decreasing motion to reduce effort," cannot be applied to all the elements of a work method. Workers must therefore make compromises between several principles in order to obtain the most efficient work method possible based on their assessment of the situation. In addition, we observed that for the right piece (Figure 5), of the three workers who move the piece of meat the most (\#2, \#5, \#6), two of them have among the lowest average bone removal times (\#2,\#6). This could be explained either by the small quick changes in position of the piece of meat that require little time or by the fact that some workers may move the piece while deboning it (simultaneously), as was mentioned by worker \#2 and observed by us. Other differences in the work methods that were observed include the manner in which the knife handle is gripped during bone removal. The types of grips that were observed are shown in Figure 7. 


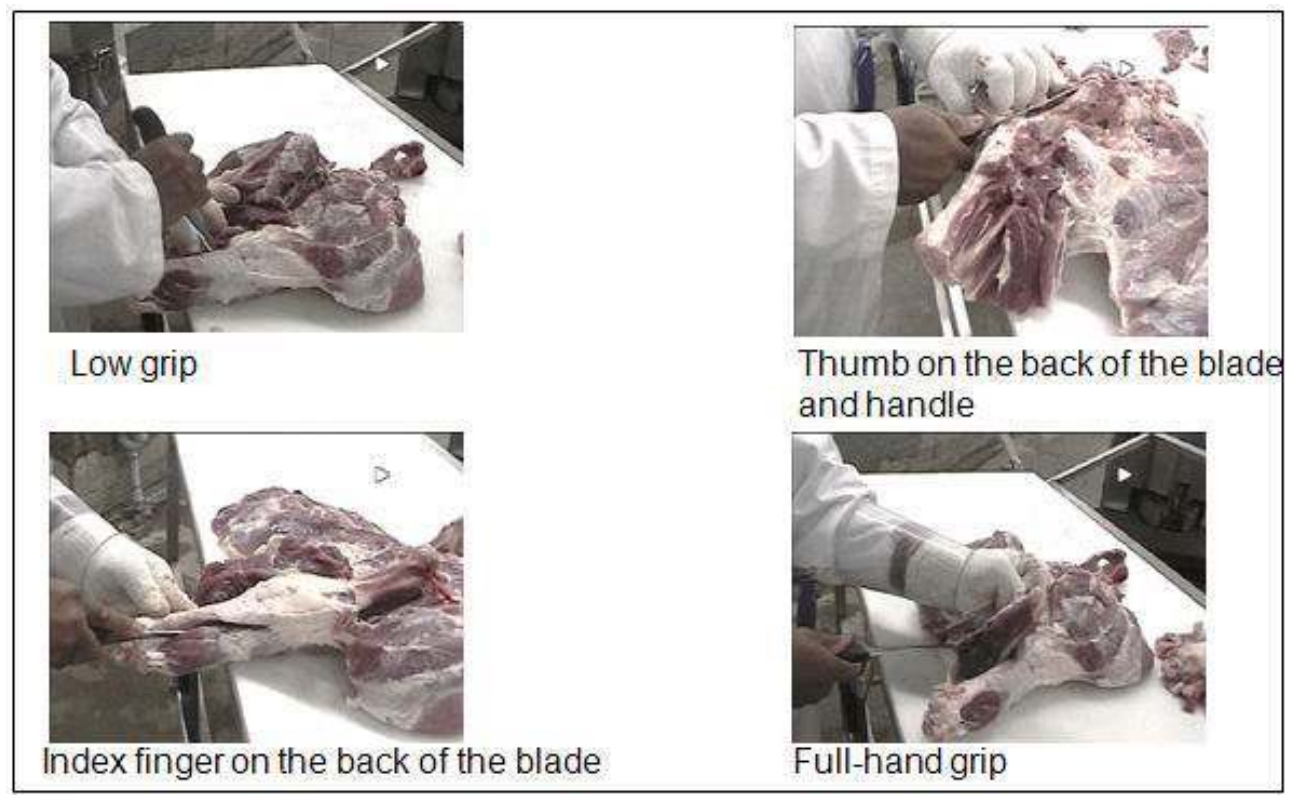

Thus, as shown in Table 2, there is considerable variability in the ways the knife handle is gripped and in the types of grips that are used. Whereas the full-hand grip could be considered the standard way of holding a knife, the data show that only worker \#5 prefers this type of grip over the others. We noted, for instance, that workers \#1 and \#6 most often use the "index on the back of the blade" grip, while worker \#2 uses the low grip and "index on the back of the blade" grip equally as often. As for worker \#3, he more often uses the "thumb on the back of the blade and handle" grip, while worker \#4 uses the "low grip" and "thumb on the back of the blade and handle" grips almost as often. The observations in fact show that the workers will change the grip based on the steps and direction of the movement. The workers mentioned using some grips such as the "index finger on the back of the blade" grip and the "thumb on the back of the blade and handle" grip for more precision and comfort. Worker \#2 even mentioned that using this grip provides him with proof that his knife is cutting well since he feels no pain in his index finger. He added that if his knife were dull, he would surely feel it in his finger. As for worker \#5, he said that he did not use this type of grip because the trainer who trained him some 20 years ago told him not to, saying that this type of grip caused wrist pain.

Table 2. Percentage of time during which a type of grip was used in relation to the total time recorded for all types of grips (right and left hams)

\begin{tabular}{|c|c|c|c|c|c|c|c|c|}
\hline \multicolumn{2}{|c|}{$\begin{array}{l}\text { Based on years } \\
\text { of experience } \\
\text { / Worker \# }\end{array}$} & $\begin{array}{l}\text { Total time } \\
\text { (seconds) }\end{array}$ & $\begin{array}{l}\text { Number of } \\
\text { changes } \\
\text { and }(\% \\
\text { time })\end{array}$ & $\begin{array}{l}\text { Low } \\
\text { grip } \\
(\% \\
\text { time })\end{array}$ & $\begin{array}{l}\text { Full } \\
\text { hand } \\
\text { ( } \% \\
\text { time) }\end{array}$ & $\begin{array}{l}\text { Index } \\
\text { finger on } \\
\text { the back } \\
\text { of the } \\
\text { blade (\% } \\
\text { time) }\end{array}$ & $\begin{array}{l}\text { Thumb on } \\
\text { the back of } \\
\text { the blade/ } \\
\text { handle } \\
\text { (\% time) }\end{array}$ & $\begin{array}{l}\text { Unknown } \\
\text { ( \% time) }\end{array}$ \\
\hline 1 & $\# 1$ & 328 & $90(12,5)$ & 23,8 & 13,1 & 32,9 & 10,4 & 7,3 \\
\hline 2 & \#3 & 252 & $56(8,3)$ & 10,3 & 11,9 & 18,6 & 50,0 & 0,8 \\
\hline
\end{tabular}




\begin{tabular}{|l|l|l|l|l|l|l|l|l|}
\hline 3 & $\# 5$ & 289 & $72(10,4)$ & 11,8 & $\mathbf{4 5 , 0}$ & 0 & 29,4 & 3,5 \\
\hline 4 & $\# 2$ & 250 & $53(9,2)$ & $\mathbf{3 2 , 0}$ & 2,0 & $\mathbf{3 2 , 0}$ & 22,8 & 2,0 \\
\hline 5 & $\# 4$ & 304 & $75(11,2)$ & $\mathbf{2 5 , 0}$ & 11,2 & 15,1 & $\mathbf{2 7 , 6}$ & 9,9 \\
\hline 6 & $\# 6$ & 279 & $64(10,4)$ & 17,2 & 11,1 & $\mathbf{3 7 , 3}$ & 22,6 & 1,4 \\
\hline
\end{tabular}

All agreed that it was important to change grips based on the steps so as to avoid using restrictive postures. The time required to change from one grip to another was recorded at the time the worker would let go of the existing grip until the next grip would be clearly used. The table shows that there is a certain percentage of time during which the types of grips could not be identified. This percentage of time corresponds to instances when it was difficult to determine on the videotape whether a worker was using the "full hand" grip or the "thumb on the back of the blade and handle" grip. Furthermore, when we compare the data on the types of grips and the data presented in Figures 5 and 6 , we see that the two workers who changed grips the least often (\#2 with 53 changes and \#3 with 56) are among the two who took the least time to remove the bone and who used the fewest knife strokes, whereas the worker who changed grips the most (\#1, with 90 changes) took the longest time to remove the bone (Figures 5 and 6), who used the most knife strokes and who moved the piece of meat the least.

In this study, we were not able to gather biomechanical data while we were videotaping due to the space constraints between the workers (assembly line) and the lack of equipment suitable for use in this type of environment. This type of data would have allowed us to expand on certain aspects with the workers, which may perhaps have made it easier to obtain a consensus. However, we can assume that the fact of changing grips on the handle takes time, even if only a fraction of a second, which may be one of the reasons accounting for worker \#1's longer work cycle. We could also ask ourselves whether the fact of not moving the piece of meat much could result in more frequent changes in grip.

\subsubsection{Use of senses while working: unsuspected physical knowledge}

As mentioned in the methodology section, during the self-assessment and group meetings, we questioned the workers about the sensory information used before and during the deboning procedure. Table 3 shows the results obtained on the information sought in connection with the senses that were used. During informal exchanges at the workstation during information gathering, the workers noted that one of the difficulties encountered in the deboning process consisted in always having to be precise in the motions, especially in some parts of the piece of meat that are not always visible. We therefore wanted to find out how the workers managed to make their motions more efficient. Five of the deboners' objectives listed in Table 3 deal with the issue of precision, while the sixth one pertains to the information used by workers to prepare for each cycle (anticipation), "to prepare the deboning process." The data first show that before each cycle (before the meat arrives), the workers visually check whether the piece is properly positioned, whether it has been properly cleaned earlier on (fat removed), and whether it is a right or left piece, in order to anticipate what they will need to do before beginning deboning, and choose the method they will be using. One of the five workers mentioned 
that he did not need to look at the meat to determine whether it was a right or left piece; he was able to determine this through touch alone.

As for the other five objectives, we can see that the workers not only used vision and touch but that some also mentioned having a mental representation of the shape and size of the bone, which allowed them to anticipate any obstacles and to position their knife adequately. We also noted that the feeling of pressing against the bone frequently came up as a way of knowing whether the knife was cutting in the right place at the correct angle as well as to anticipate any obstacles. One of the workers (\#6, with 25 years experience) claimed being able to debone without looking and of immediately knowing the outcome of his work by touch. Another worker (\#2) said that it was important to not hold the knife too tightly in order to feel the bone. Note that the latter two workers are among those with the most experience in the meat industry.

The data presented in Table 3 show the importance of knowledge and of visual or tactile recognition of the characteristics of raw materials. This observation brings up the question of the learning difficulties that may be encountered by trainees in this type of work, which has such perceptual-motor requirements. How can the development of perceptual-motor skills that experienced workers have be favoured without having to go through years of painstaking and painful practice? In addition, considering that a dull knife and a novice's stress can lead to a tight grip on the handle, this makes us think that it would be important to take action on certain influencing factors before a worker is able to have a "relaxed "grip".

Table 3. Information sought by workers while carrying out the task and knowledge bridges (number of workers who brought up this aspect)

\begin{tabular}{|c|c|c|c|}
\hline \multirow{2}{*}{$\begin{array}{l}\text { Target } \\
\text { objectives }\end{array}$} & \multicolumn{2}{|c|}{$\begin{array}{l}\text { Information being sought } \\
\text { CHECK... }\end{array}$} & \multirow{2}{*}{\begin{tabular}{|l|} 
Knowledge bridges \\
Mental image
\end{tabular}} \\
\hline & Visual & Tactile & \\
\hline $\begin{array}{l}\text { Prepare for } \\
\text { deboning (before } \\
\text { starting) }\end{array}$ & $\begin{array}{l}\text { Whether the piece has } \\
\text { been properly cleaned } \\
\text { (prior step) (2) } \\
\text { Whether the piece is } \\
\text { properly laid out } \\
\text { before starting (4) } \\
\text { Whether there is an } \\
\text { abcess (1) } \\
\text { Whether it's a right or } \\
\text { left piece (3) }\end{array}$ & $\begin{array}{l}\text { Shape of the piece } \\
\text { (know whether it's a } \\
\text { right or left piece) (1) }\end{array}$ & \\
\hline $\begin{array}{l}\text { Know where to } \\
\text { have the knife go } \\
\text { to trace the } \\
\text { "inside" piece }\end{array}$ & $\begin{array}{l}\text { Where the "femur } \\
\text { ball" is to begin beside } \\
\text { it; line of fat (1) } \\
\text { Where the "femur } \\
\text { ball" is to begin below } \\
\text { Where the line of fat is } \\
\text { to follow it (4) }\end{array}$ & $\begin{array}{l}\text { Leaning against the } \\
\text { bone (1) }\end{array}$ & $\begin{array}{l}\text { Shape of the bone under } \\
\text { the meat (1) }\end{array}$ \\
\hline
\end{tabular}




\begin{tabular}{|c|c|c|c|}
\hline $\begin{array}{l}\text { Know whether } \\
\text { the knife is } \\
\text { entering at the } \\
\text { right location }\end{array}$ & Where the bone is ( 3 ) & $\begin{array}{l}\text { Leaning against the } \\
\text { bone (4) } \\
\text { Different texture of the } \\
\text { meat and cartilage (1) } \\
\text { Bone deformations (2) }\end{array}$ & \\
\hline $\begin{array}{l}\text { Know the correct } \\
\text { blade depth }\end{array}$ & $\begin{array}{l}\text { Results (1) } \\
\text { Bone thickness (1) } \\
\text { Distance between } \\
\text { hand and meat (low } \\
\text { grip) or distance } \\
\text { between fingers and } \\
\text { meat (other grips) (1) }\end{array}$ & & $\begin{array}{l}\text { Diameter and thickness } \\
\text { of the bone (2) }\end{array}$ \\
\hline $\begin{array}{l}\text { Anticipate } \\
\text { obstacles }\end{array}$ & & $\begin{array}{l}\text { Feeling the change in } \\
\text { the shape of the bone, } \\
\text { which is larger before } \\
\text { reaching the joint (1) }\end{array}$ & $\begin{array}{l}\text { Distance covered by the } \\
\text { knife compared to the } \\
\text { mental image of the non- } \\
\text { visible length of the } \\
\text { bone (1) }\end{array}$ \\
\hline $\begin{array}{l}\text { Have the correct } \\
\text { angle of the knife }\end{array}$ & Shape of the bone (1) & $\begin{array}{l}\text { Leaning against the } \\
\text { bone (2) }\end{array}$ & Shape of the bone (2) \\
\hline
\end{tabular}

\subsection{In-depth gestural analysis aimed at identifying knowledge and skills}

\subsubsection{Skill development as a protective measure}

The detailed description of the operating modes and in-depth analysis of the experienced workers' motions allowed the skills to be described along with a verbalization of the knowledge applied in the implementation of the skills. These skills include those that have been identified more as production-related, i.e. needed to meet quality-related requirements, and others that have been developed by the workers as a protective measure (preventive skills), without disregarding production-related requirements. As mentioned in the introduction, it is customary in ergonomic studies aimed at preventing musculoskeletal disorders to want to understand how experienced workers succeed in protecting themselves by applying the preventive skills they have developed. However, is there not a risk that this emphasis on preventive skills will neglect the possible contribution of certain skills identified as "production-related" to preserve the workers' health, as indicated by the results obtained during the study? In fact, whereas certain skills had first been associated with attaining a level of quality sought by the workers, they were subsequently correlated with the fact that they allow the efforts and repeated motions to be decreased by reducing the number of required knife strokes. Note, in particular, the skill of "having the knife penetrate at the right spot" and "using the appropriate part of the knife's blade," for which there was a consensus among the experienced workers. Having the knife penetrate at the right place means properly applying the knife's blade over the bone and having the blade pass between the parts (natural tracts) of the piece of 
meat. When the workers were made to talk about their work method during selfassessment and group meetings, they explained that this skill allows them, on the one hand, to decrease the effort required since there is a thin space between each part of the piece of meat made up of a membrane that is easy to cut and, on the other hand, to reduce the number of knife strokes since this avoids tearing the fat and membranes that must be removed from the "inside" piece during the sequence. As for the skill involving "using the appropriate part of the knife's blade," it enables, according to the experienced workers, to decrease the effort required by avoiding running up against the bones, which could damage the blade and increase the number of knife strokes. This skill could also facilitate the work of personnel at the workstation further down the line (finishing) who are in charge of cleaning the pieces of meat. The importance of developing these two types of skills is therefore not to be neglected if a worker wants to be protected.

Furthermore, how can the preventive skills used by experienced workers in this work context be identified? Can preventive skills be determined without alluding to production since these skills are expressed in a production-related environment? Our discussion based on the results obtained and talks with workers led us to formulate the skills by always starting with "removing the bone by..." to emphasize the fact that this skill is meaningful when expressed within the task. Given that the results obtained in this phase will be used to analyze the transmission of knowledge to trainees as part of a second phase of the study, we have chosen to present the results regarding the company's two worker-trainers. Table 4 lists the preventive skills identified based on these workertrainers as well as the two previously mentioned skills that are more associated with production.

Table 4. List of main preventive skills and production-related skills for each worker-trainer

\begin{tabular}{|l|l|l|}
\hline Preventive skills & $\begin{array}{l}\text { Worker- } \\
\text { trainer 1 }\end{array}$ & $\begin{array}{l}\text { Worker- } \\
\text { trainer 2 }\end{array}$ \\
\hline $\begin{array}{l}\text { Removing the bone by choosing the moment to open the cinside" } \\
\text { piece based on circumstances to avoid touching the co-worker } \\
\text { down the line }\end{array}$ & $\mathrm{X}$ & $\mathrm{X}$ \\
\hline $\begin{array}{l}\text { Removing the bone by choosing the types of grips on the knife } \\
\text { based on the steps to decrease the effort required and restrictive } \\
\text { postures }\end{array}$ & $\mathrm{X}$ & $\mathrm{X}$ \\
\hline $\begin{array}{l}\text { Removing the bone by striking a balance between the number of } \\
\text { motions of the body and piece of meat in order to be comfortable } \\
\text { and reduce the effort required }\end{array}$ & $\mathrm{X}$ & $\mathrm{X}$ \\
\hline $\begin{array}{l}\text { Removing the bone by using the minimum required number of } \\
\text { knife strokes to reduce the effort }\end{array}$ & $\mathrm{X}$ \\
\hline $\begin{array}{l}\text { Removing the bone by positioning the non-dominant hand to avoid } \\
\text { injury }\end{array}$ & $\mathrm{X}$ \\
\hline $\begin{array}{l}\text { Removing the bone by positioning the piece of meat or by } \\
\text { positioning oneself so as to reduce restrictive postures }\end{array}$ & $\mathrm{X}$ \\
\hline
\end{tabular}




\begin{tabular}{|l|l|l|l|}
\hline Removing the bone by ensuring good cutting to reduce the effort & $\mathrm{X}$ & $\mathrm{X}$ \\
\hline $\begin{array}{l}\text { Removing the bone by managing the time allotted to ensure } \\
\text { manoeuvrability }\end{array}$ & $\mathrm{X}$ & $\mathrm{X}$ \\
\hline $\begin{array}{l}\text { Removing the bone by anticipating difficulties to ensure some } \\
\text { manoeuvrability }\end{array}$ & $\mathrm{X}$ \\
\hline Production-related skills & $\mathrm{X}$ \\
\hline $\begin{array}{l}\text { Removing the bone by placing the knife at the right location to } \\
\text { ensure good quality }\end{array}$ & $\mathrm{X}$ & $\mathrm{X}$ \\
\hline $\begin{array}{l}\text { Removing the bone by using the good part of the knife's blade based } \\
\text { on the steps to ensure good quality }\end{array}$ & $\mathrm{X}$ & \\
\hline
\end{tabular}

We thus noted that in order to protect themselves, the worker-trainers would choose the moment to begin the process of opening the "inside" part of the piece of meat, choose the types of grips on the knife handle based on the steps involved, strike a balance between the number of knife strokes and number of motions of the body and piece of meat, position themselves, or position the piece of meat to avoid injury and restrictive postures, ensure good cutting quality, manage their time, and anticipate any problems in order to give themselves some manoeuvrability. Note also that the two worker-trainers exhibited the same skills, except that of "removing the bone by positioning the non-dominant hand to avoid injury" and that of "removing the bone by using the minimum number of required knife strokes to reduce the effort," which were not observed and expressed by worker-trainer \#1. In the section that follows, we will see whether these two workertrainers apply the same knowledge to implement these skills.

\subsubsection{Applying knowledge for skills}

The in-depth gestural analysis as well as the verbalizations during the self-assessment and group meetings also allowed the types of knowledge applied by the worker-trainers to be determined. The methods used consisted of observation, the individual selfassessment meeting and the group meeting. Note that in order to show the contribution of the self-assessment and group meetings, we separated the observable component of the motion such as "opening and cleaning the 'inside' during or after deboning" from the associated cognitive or intentional component "to avoid the co-worker down the line." Whereas observations enabled us to describe the actions and postures, the individual and group meetings led to a verbalization of the target objectives, the cues used, the information sought after in relation to the task, and to obtain a level of refinement in the analysis of the actions, which is difficult to achieve through observation. The meetings also helped us understand how the workers deal with production-related constraints and the logic behind some of the compromises. For instance, for the "open and clean the 'inside' during or after deboning" know-how, we were able to determine, based on observations, that worker-trainer \#1 opens the "inside" piece at the beginning of the sequence for the right piece of meat since this part is provided first. However, he opens this part at the end of the sequence for the left piece since this "inside" part is provided last. Worker-trainer \#1 said that if he did not open the "inside" part of the right piece at 
the start (arrives first), he might be too far into his co-worker's space down the line since the piece is moving away from him.

As for worker-trainer \#2, we observed that he opens the "inside" part at the start of the sequence regardless of whether a right or left piece is involved. Since the "inside" part of the left piece is located to his left and the conveyor is moving left to right, worker \#2 said he found there to be some disadvantage in opening the "inside" part of the left piece at the start of the sequence. In fact, while a worker is removing the left side of the piece and opening up the "inside" part located to his left before doing the right side, the piece was moving away from him when comes time to remove that side. However, if this worker proceeds in this way, it is because he sees it as an opportunity to save time since he must in any case remove the inside of the bone on the left that is also found on the same side as the "inside" part. Therefore, according to worker-trainer \#2, the fact of doing everything that needs to be done on one side of the piece before moving on to the other side saves a few seconds. In this trade characterized by very short work cycles, saving even one second is very important to workers. Each second saved can lead to a micro-break and a small degree of maneuverability. Note that worker-trainer \#2 is one of the two workers with the shortest average deboning time.

Different knowledge could be identified, including: 1- characteristics of the pieces of meat and bone; 2- positioning the piece of meat close to the body to avoid having outstretched arms; 3positioning the piece of meat at an angle or worker positioned at an angle to avoid getting 'caught up' and crooked; 4- sequence to follow in some of the steps to make the work easier to do; 5useful parts of the blade to use; 6- use of a long cutting motion and; 7- use of a full grip on the handle, considered as the standard grip by suppliers. Note that the knowledge related to the characteristics of the pieces of meat and the bone were deemed to be essential for successful deboning. The comment made by worker-trainer \#1 at the self-assessment meeting shows this importance: "You need to know how the bone is made up. Well, I don't try to figure it out anymore... I remember that, like the underside of the hock, the bone that is completely under that is tilted a little... Mr. X he removed it, he's looking at me, it's not straight... But as long as he hasn't shown it to me..." In addition, we would like to make note of a fact that clearly illustrates the contribution that the practical testing period in the production room during the group meeting may have had. In fact, during the self-assessment and group meetings in the room, the workers were frequently heard to say that one of the important aspects for successful deboning was to use the appropriate part of the blade of the knife, i.e. the "tip" of the blade. But listening to the workers, two questions emerged, namely one being of knowing what the workers meant by "tip" of the blade and the other being whether the tip was truly always the part that was used. This last aspect was difficult to observe from the videotaped sequences. During the tests in the production room, we were able to show that the workers each had a different image of what the "tip" of the blade represented for them, and that for certain steps, a larger part of the blade was used. For some, the "tip" was only a small part of the end of the blade, whereas for others, it represented about a third of the length of the blade. However, they all said that the secret of deboning was to work with the "tip" of the blade. The practical tests thus revealed each worker's mental representation of the notion of knife "tip," allowed them to become aware that finally in practice, it was not always this part of the blade that was used even though it was in fact the main part involved and, finally, to understand the reasoning underlying the choice of the length of blade to use based on the steps involved. 
Moreover, from the standpoint of training, we wondered about the relationship between skills on the one hand and the different types of knowledge on the other. Were there any prerequisites to the development of certain skills and knowledge? This line of thinking led us to build a hierarchical chain of skills and knowledge by using as an example the case of the preventive skill of "removing the bone while using the required minimum number of knife strokes" (Figure 8). Hence, as shown in Figure 8, to own this skill, the experienced workers had to develop prerequisite skills that were more production-oriented such as "using the appropriate part of the blade," "having the knife penetrate at the right spot" and a skill that was more associated with the reduction of efforts, and hence of prevention, which was to "ensure the knife was cutting well." These skills themselves involve the application of a variety of knowledge to be acquired, integrated and/or developed, such as the characteristics of raw materials, the steps to follow, tricks and cues, as well as knowledge related to "personal skills" to facilitate the deboning process, such as the principle of "being attentive to the execution process." This chain of prior knowledge and skills thus assumes that in the exercising of care, a worker must first acquire different knowledge in order to develop other skills that will allow him to use fewer knife strokes. This knowledge and skill hierarchy can thus have a major impact on the training of new workers.

Figure 8. Hierarchy of knowledge and know-how that are prerequisites for the preventive know-how of "removing the bone by using the required minimum number of knife strokes"

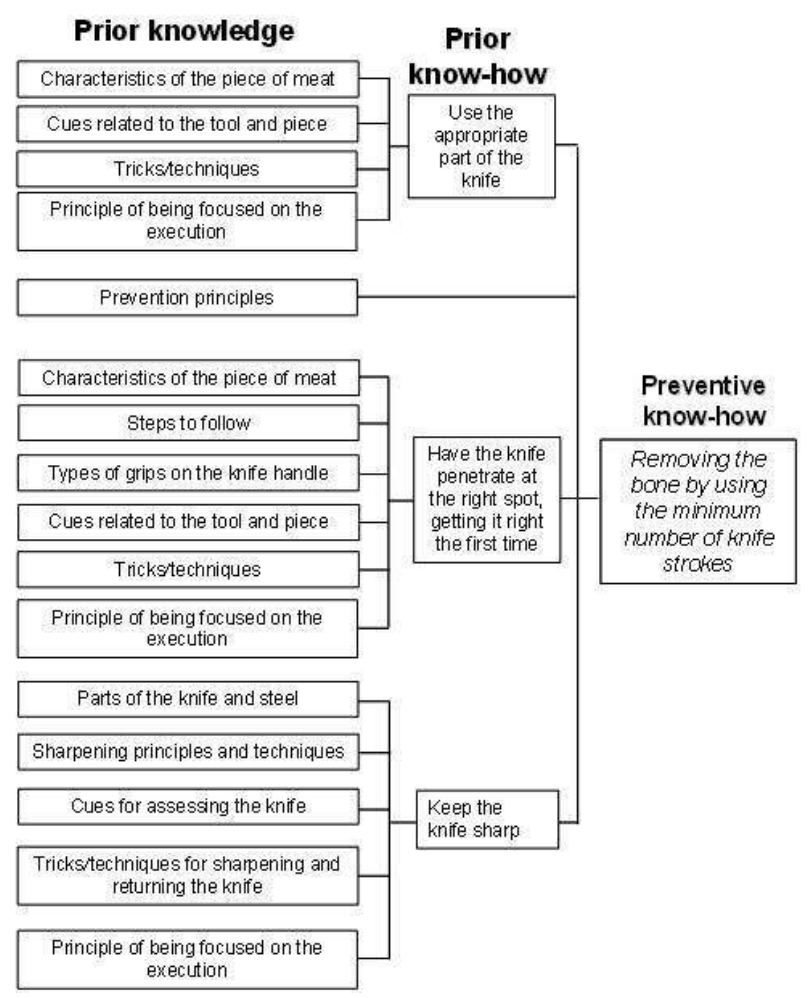

Another interesting fact based on the results is that a preventive skill such as "removing the bone by using the required minimum number of knife strokes" can not only have an impact on health but also on production. In fact, when we asked workers to list the advantages of using fewer knife strokes, they said that this not only leads to a reduction in effort but also allows the pace to be observed and to have a beautiful finished product. There thus appears to be a grey area between "production skills" and "preventive skills." Can they 
exist exclusively for production or prevention? Based on our study findings, there appears to be no evidence in this respect.

In an effort to analyze the data even further, we documented the relationship that may exist between certain types of knowledge. To do so, we built a hierarchy chain (Figure 9) between the knowledge that is applied for the skill of "having the knife penetrate at the right spot" shown previously in Figure 8.

Figure 9. Hierarchy of prior knowledge for the know-how of "having the knife penetrate at the right spot"

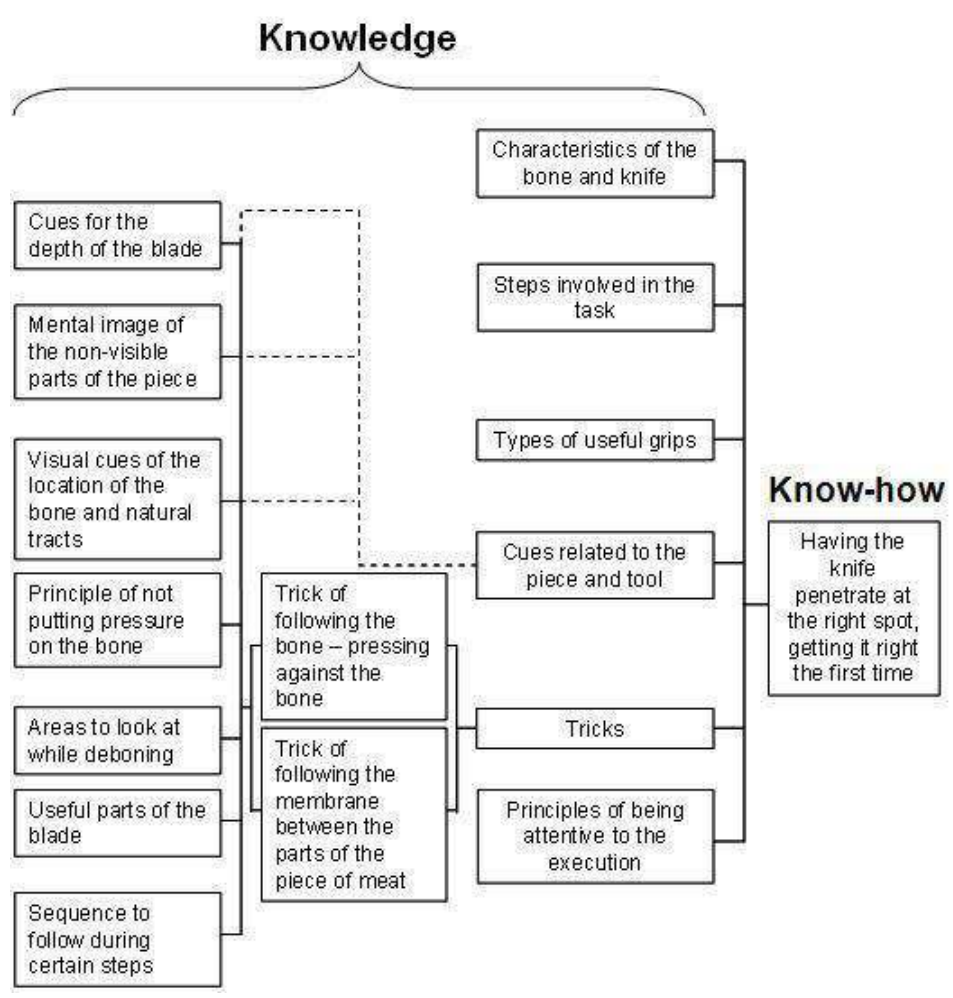

49 As shown in Figure 9, two tricks can be passed on so that the worker is able to have the knife penetrate at the right spot, i.e. "follow the bone - pressing against the bone" and "follow the membrane between the parts of the piece of meat." The question that we attempted to answer was: "Is there knowledge that must be transmitted if these tricks are to permit the skill to be implemented? The figure shows that other knowledge in fact had to be developed for these tricks of the trade to be developed, such as: 1- useful parts of the blade; 2- sequence to follow in some of the steps; 3- principle of not applying any pressure on the knife handle, etc. Hence, these last two figures show that there is a certain hierarchy in the development of knowledge and skills that must be considered to favour skill development. 


\section{Discussion}

\subsection{Formalizing the knowledge and skills of experienced workers: necessity or option?} more on the biomechanical component. This perception often leads to the belief that a repetitive task can be learned quickly and that all that is needed is to observe the other workers in order to be able to do the work. However, an in-depth gestural analysis and the discussions with workers revealed that over time and with experience, the workers developed knowledge that allowed them to apply skills aimed at solving day-to-day problems and to create manoeuvrability as well as protect themselves and others, and meet production-related requirements, as shown by Teiger and Laville (1989). The variability found in the operating modes shows how each of these experienced workers developed a deboning method based on his characteristics, abilities, values and understanding of the situations encountered.

51

Why formalize the knowledge and skills of experienced workers? In several companies, especially in the agri-food industry, training is being increasingly seen as a way to prevent musculoskeletal disorders. In this respect, experienced workers are often called upon to act as trainers when asked to transmit the knowledge they have acquired, developed and incorporated in their work. This knowledge is associated with the performance of the task itself (motions, sensorimotor perception, planning) as well as the characteristics of the raw material that is to be processed, the tools being used, and the various conditions to take into account. As previously mentioned, the knowledge related to the operating modes was developed based on the workers' characteristics. Since the knowledge that a given experienced worker has is not necessarily suitable for a trainee, it is important to be able to formalize the knowledge of several experienced workers in order to offer trainees the possibility of choosing the one most suited to their characteristics.

Meanwhile, some authors (Teiger, 1996; Daniellou and Garrigou, 1995, Reber, 1989) write about the difficulty workers have in verbalizing their knowledge when asked about their work methods, in particular the practical knowledge they incorporate and which includes the knowledge applied in preventive skills. Could this verbalizing difficulty also not occur when a worker is required to instruct trainees? As a result, can the objective of preventing MSDs through training really be attained? This leads us believe that attaining this prevention objective requires that the knowledge and skills of experienced workers be formalized so that: 1- knowledge, especially practical knowledge, be made transmissible in order to favour the development of preventive skills; 2- the knowledge related to the completion of a task be defined and, as a result, new types of technical documentation be drawn up and the means of improving the understanding of the work be provided; 3- the requirements of the task be described in all its facets (biomechanical, cognitive and psychological) and the knowledge that trainees must acquire to carry out the work while ensuring they are protected be documented; and 4- the difficulty of learning a task be anticipated and the training set up accordingly. 


\subsection{Professional skills: are there prerequisites for their development?}

In addition to the importance of the physical component, the deboning task, to be properly carried out, requires that workers grasp a considerable amount of information and have control over their surroundings and their own selves. Furthermore, contrary to what may sometimes be perceived, the workers are not passive regarding work-related risks. They develop preventive skills and strategies to manage these risks (Cru, 1995). The development of skills requires the application of a set of knowledge that has been acquired through formal or informal training or developed through practice. For instance, Figure 10 shows an overview of all the knowledge that has been applied in order to be able to "have the knife penetrate at the right spot," a skill that is more associated with the quality of production but that allows workers to exert less force to cut the piece of meat and use fewer knife strokes to attain a given level of quality.

To develop this skill, a worker must not only acquire and apply theoretical knowledge but also develop practical knowledge that will validate and build on all the theoretical knowledge over time. Note, however, that in the absence of training, such theoretical knowledge may have to be acquired "on the fly," i.e. in practice. Theoretical knowledge primarily consists of knowledge of the characteristics of raw materials and of available equipment (e.g. names and locations of the parts of the piece of meat, types of knives available), knowledge of the quality criteria and prevention principles and knowledge of procedures. Practical knowledge, for its part, includes the lists of possible solutions, cues and tricks of the trade (e.g. cues for the blade's depth of penetration), the list of techniques (e.g. relationship between the types of grips on the knife/steps/positioning of the piece of meat) as well as the memory of past experiences (e.g. "doing that hurt my wrist"). This knowledge, once formalized, can be acquired as part of formal or informal training, but in the case of our worker-trainers, it was almost entirely developed in practice. In addition, personal skills can contribute to the implementation of regular skills that will allow workers to attain the objective being targeted. Some of the personal skills mentioned by the workers and shown in Figure 10 include concentration, attention, openness to learn and develop new work methods along with the exercise of care. The dotted circle that links knowledge and personal skills aims to show the mutual influence that the workers' knowledge and personal skills can have. 
Figure 10. Model of the application of a set of knowledge applied to the efficient know-how of " having the knife penetrate at the right spot by positioning the piece of meat so as to reduce postural constraints"

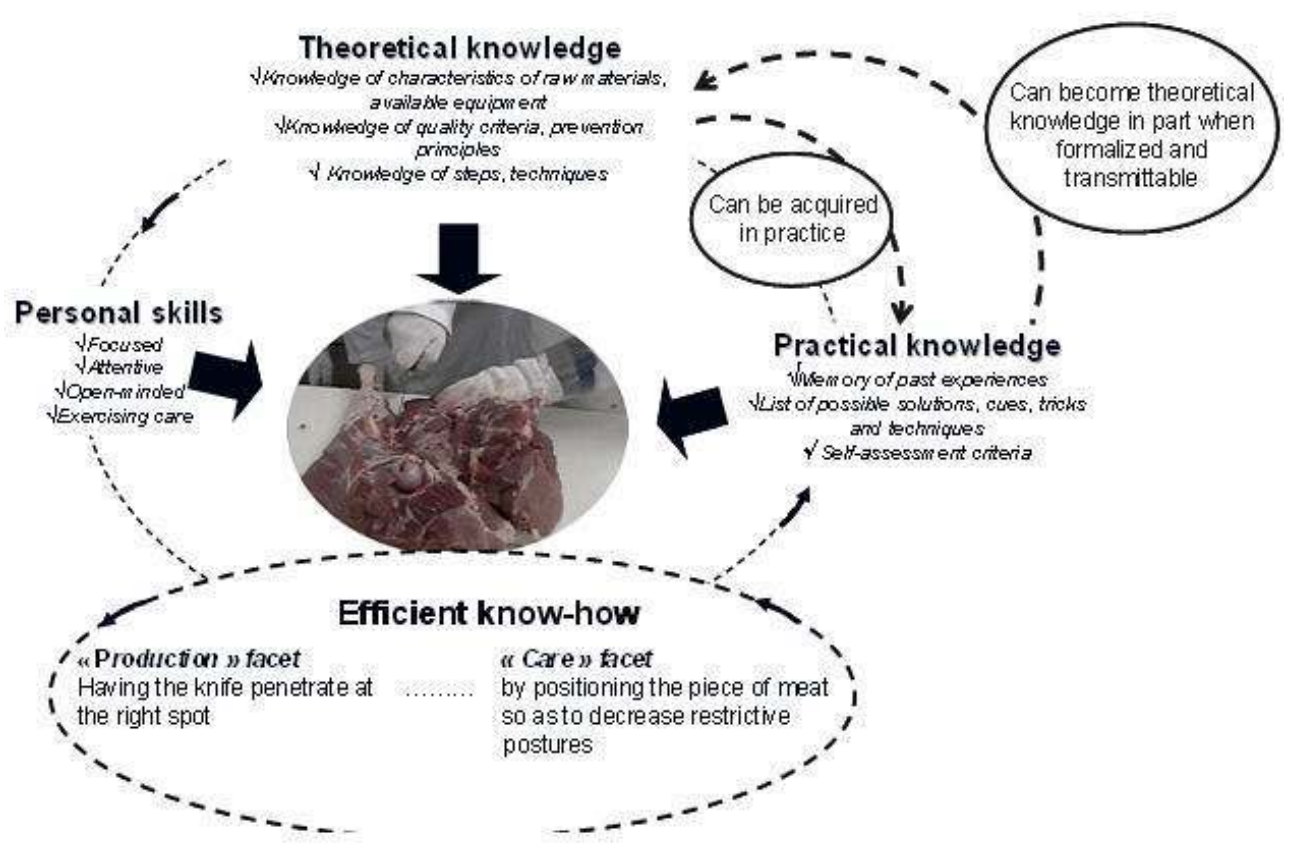

An increasing number of studies deal with the issues of training and the transmission of knowledge (Chatigny et al., 2006; Fournier, 2003; Cloutier et al., 2002) and as previously mentioned, where MSD prevention is involved, the emphasis is usually on identifying the preventive aspect of the knowledge and skills of experienced workers in order to favour their development among trainees. But is there a hierarchy in skills development? Can the "preventive" aspect be developed before the production aspect? The data presented earlier in Figures 8 and 9 seem to indicate that this is not the case. We determined that to develop the knowledge of "removing the bone by using the required minimum number of knife strokes," workers first had to develop two skills that are more associated with production, namely that of "using the appropriate part of the blade," "having the knife penetrate at the right spot," and a skill more associated with the exercise of care, that of "keeping the knife sharp." These skills themselves involve the application of substantial knowledge. Therefore, there appears to be a whole crucial development stage between "wanting to exercise care" (personal skill) and "being able to do so" ("care" aspect). This stage could correspond to a phase of "being capable of doing" that is based on the concept of "being able to act" by Le Boterf (2006, p. 91), determined by the context and conditions provided to workers for developing the skill in question. It is therefore important to consider these prerequisites when determining how the training will be structured, what the content will be, and what conditions will have to be offered to favour the development of these skills. The notion of "prerequisites" naturally assumes the involvement of a "time" factor in the development of the skills and the need to have realistic expectations as to a trainee's capacity to protect himself. 


\subsection{Production skills vs. preventive skills, or a combination of the}

\section{two}

Furthermore, if we are looking to develop training aimed at preventing musculoskeletal disorders through an ergonomic approach, what types of knowledge and skills should we be looking to identify? In this respect, in ergonomic studies aimed at preventing MSDs (Denis et al., 2007; Chassaing, 2006; Chatigny, 2001; Authier, 1996; Gaudart; 1996), the emphasis is usually placed on identifying tricks of the trade and strategies developed by experienced workers as a measure of protection (preventive skill). On the other hand, the results obtained during the study show that in some cases, skills identified for production (quality) can also prove to be very useful for decreasing effort and repeated motions and that in other cases, it is skills first identified for protection purposes that can also be useful for production, such as "removing the bone by using the required minimum number of knife strokes." With respect to designing training content that favours MSD prevention, would it not be more appropriate to approach the study on skills by situating them in terms of the impact on production and health and then to identify the knowledge that needs to be acquired to implement the skills? This integrated approach of looking at the concept of skill is found along the same lines as the ergonomic approach used in this study, which takes the integrative nature of the task into account (Guérin et al., 2006). Hence, shouldn't the expression "efficient skill" be used rather than "preventive skill" and "production skill"? "Production" and "the exercise of care" would represent the two facets of this skill. An "efficient skill" would be "a person's ability to apply in his/her work a set of knowledge that allows him/her to meet an objective aimed at both production and the protection of one's health and that of others." Figure 11 shows an example of how an efficient skill would be expressed with its two facets of "production" and "the exercise of care."

Figure 11. Example of an efficient know-how with its facets of "production" and "the exercise of care"

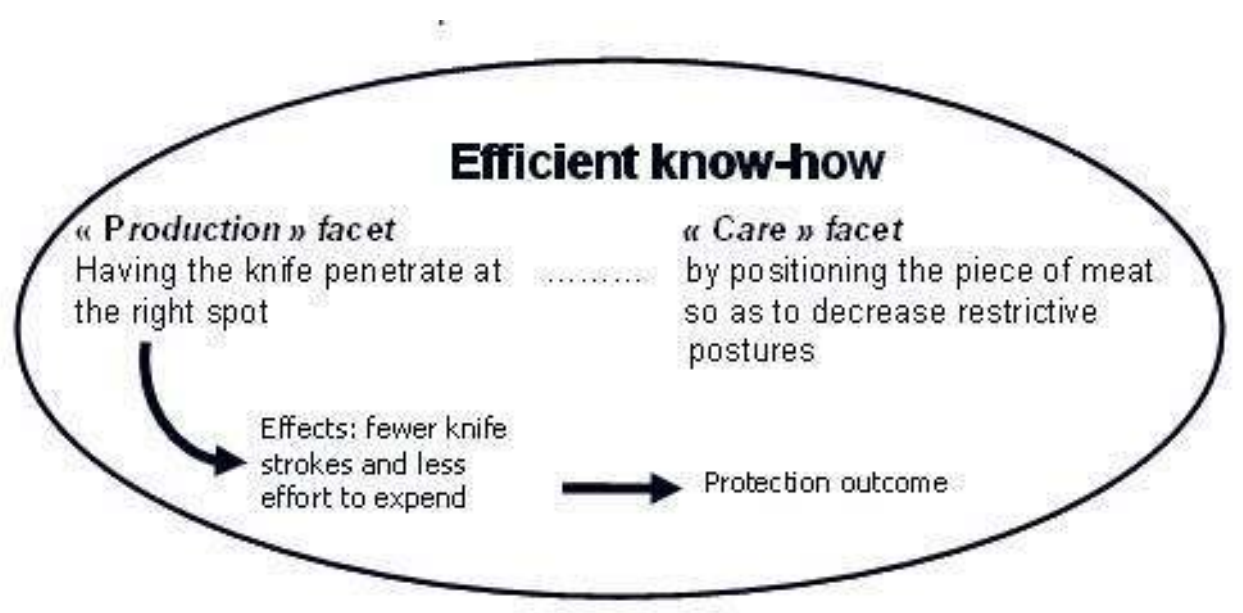




\section{Conclusion}

\subsection{Strengths and limitations of the study and research prospects} the skills of the experienced workers - specifically those of the two worker-trainers - as well as facilitating the verbalization of knowledge. The observation and verbalization stages that were carried out among a group of experienced workers resulted in an indepth understanding of the job task, allowed an in-depth analysis to be done of the operating modes and workers' motions, and favoured the verbalization of the practical knowledge developed over time to facilitate the work. The distinctive nature of this study mainly resides in this in-depth description of the work motions carried out within the analysis of the work, which led to a series of questions specifically designed to identify the sensory facets used by the workers to carry out the task. A strength of the group meeting was the use of visual means and practical tests in the production room, which proved highly instructive because they allowed the workers to verbalize their knowledge on the action and in the action. It is important to mention that the approach presented in the study was not intended to be an already existing approach with a series of stages carried out in a rigid sequence but rather an approach developed during the course of the work with the active involvement of the company's various representatives.

The study served to show how the ergonomic analysis contributed to a description of the professional motions as defined by Bourgeois et al. (2006), but it should be stressed that in order to answer questions on very specific aspects on the motions that were carried out, this approach has some limitations. In fact, though very comprehensive, the approach is limited to a qualitative assessment of the motion that is done, which does not allow quantitative data to be obtained on the muscular effort, the specific angling of the segments during the work, the pressure exerted by the fingers on the knife, and the speed of the motion. These data may have been useful to the discussions with the workers in order to help with the verbalization of knowledge. Where possible, it would be relevant to consider integrating biomechanical measures (Richard, 2002) in the studies aimed at drawing up training programs in order to be able to answer questions that may even be asked by the workers, such as the level of risk found in certain work methods such as the way the knife is held. The interdisciplinarity interest in this type of study stems from the fact that the qualitative analysis used to describe the variability of the professional motions leads to certain questions that could be explained in part through a quantitative biomechanical or physiological analysis.

Furthermore, even though we believe that the approach and methods used enabled several skills to be identified and the verbalization of a range of the experienced workers' knowledge, we cannot claim to have succeeded in identifying everything. It is probably not possible to have the workers verbalize all the knowledge they acquired. However, the collection of quantitative data, as previously mentioned, would quite likely allow this formalization of knowledge to be developed in greater depth. In addition, the workers said that the meetings held in conjunction with the study would have them reflect on their work practices. Some would leave a meeting saying that they wanted to check what they did in certain circumstances. We believe that it would be important to develop a mode of thinking in the company that would favour the continuation of training 
development by enhancing the training content through the integration of other practical knowledge arising from an ongoing reflection process on the part of the workertrainers.

\subsection{Scope of the study findings}

60 Is such an approach that favours an in-depth analysis of work-related motions necessary and useful only in situations where there is repetitive manual work? In our opinion, regardless of the trade involved, there will always be a need to describe and understand all of the components of work-related motions if we wish, on the one hand, to obtain training contents that are representative of actual work and, on the other, to favour the development of skills through the transmission of professional knowledge. Workers in these types of positions have often had to learn "on the fly" and take years - at times difficult and painful - to succeed in developing these tricks of the trade that made their work easier. Since suffering should never be a rite of passage for the learning of a task, it is important that the development of these skills be facilitated through the transmission of knowledge to new workers.

61 It should also be mentioned that a major contribution of the study was the design of a deboning training manual which was handed out to and validated by the company's worker-trainers (Ouellet, 2006). A follow-up to this project could be to check how the manual could be standardized for the pork processing industry.

The authors wish to thank management as well as the workers, their representatives and the company representatives who enabled this research project to be carried out. The authors are solely responsible for the content of this article.

\section{BIBLIOGRAPHY}

Authier, M. (1996). Analyse ergonomique des stratégies de manutentionnaires experts et novices. Thèse de doctorat. Département d'éducation physique. Université de Montréal, Montréal.

Barbier, J.M., Galatanu, O. (2004). Savoirs, capacités, compétences, organisation des champs conceptuels. In Les savoirs d'action : une mise en mots des compétences?, eds J.M. Barbier, O. Galatanu, p. 31-78. Édition L'Harmattan, Paris.

Berthoz, A. (1997). Le sens du mouvement. Éditions Odile Jacob, Paris, 345 p.

Bouisset, S., (2002). Biomécanique et physiologie du mouvement. Masson, Paris. 304 p.

Bourgeois, F., Kemarchand, C., Hubault, F., Brun, C., Polin, A., Faucheux, J.M. (2006). Troubles musculo-squelettiques et travail - Quand la santé interroge l'organisation. Collection Outils et Méthodes, ANACT. 308 p.

Bourgeois, F., Hubault, F. (2005). Prévenir les TMS. De la biomécanique à la revalorisation du travail, l'analyse du geste dans toutes ses dimensions. Activités, vol. 2, $\mathrm{n}^{\circ} 1$, www.activites.org/ v2n1/html/bourgeois.html 
Bril, B., Roux, V. (2002). Le geste technique. Réflexions méthodologiques et anthropologiques. Éditions Éres, Ramonville Saint-Agne. 309 p.

Chassaing, K. (2006). Élaboration, structuration et réalisation des gestuelles de travail : les gestes dans l'assemblage automobile et dans le coffrage des ponts d'autoroute. Thèse de doctorat, spécialité ergonomie. Conservatoire National des Arts et Métiers, Paris, 279 p.

Chatigny, C., Balleux, A., Martin, M., Grenier, J., Ouellet, S., Corbeil, M., Laberge, M., Rochette, D. (2006). Étude exploratoire des dynamiques de formation et d'apprentissage : apprentissage des tâches et prévention des troubles musculo-squelettiques dans trois entreprises du secteur avicole. Études et recherches, IRSST, R-464, Montréal, 80 p., www.irsst.qc.ca/fr/ _publicationirsst_100202.html

Chatigny, C., Vézina, N. (2004). Le développement des compétences : Enjeux de santé et de sécurité au travail. $13^{\mathrm{e}}$ Congrès de psychologie du travail et des organisations, AIPTLF - Bologna, Communication C187, Thème : 4.1 Analyse du travail.

Chatigny, C., (2001a). Polyvalence et développement des compétences : quelques obstacles identifiés lors d'études portant sur les conditions d'apprentissage en entreprise. Comptes rendus $31^{\mathrm{e}}$ Congrès annuel de l'ACE - Ergonomie et sécurité. Hull.

Chatigny, C. (2001b). La construction de ressources opératoires. Construction à la conception des conditions de formation en situation de travail. Thèse de doctorat. Conservatoire National des Arts et Métiers, Paris. 285 p.

Chatigny, C., Vézina, N. (1994). Analyse du travail et apprentissage d'une tâche complexe ; étude de l'affilage du couteau dans un abattoir. Le Travail Humain, 59, p. 229-252.

Chatigny, C. (1993). Étude des conditions d'apprentissage du métier dans un abattoir de porc. Mémoire de maîtrise. Université du Québec à Montréal, Montréal.

Chatigny, C., Vézina, N. (1992). Analyse de l'affilage du couteau dans un abattoir de porc. $25^{\mathrm{e}}$ Congrès de l'Association canadienne d'ergonomie.

Chevallier, D., Chiva, I. (1991). L'introuvable objet de la transmission. In Savoir-faire et pouvoir transmettre. Mission du Patrimoine ethnologique Collection Ethnologique de la France, Cahier 6, ed. D. Chevallier, p. 1-11. Éditions de la Maison des sciences de l'homme, Paris.

Chevallier, D. (1989). Le programme savoir-faire et techniques. Terrain, revue de l'ethnologie de l'Europe, Du congélateur au déménagement. Pratiques de consommation familiale. $\mathrm{n}^{\circ}$ 12, p. 1-6.

Cloutier, E., Lefebvre, S., Ledoux, É., Chatigny, C., St-Jacques, Y. (2002). Enjeux de santé et de sécurité au travail dans la transmission des savoirs professionnels : le cas des usineurs et des cuisiniers. Études et recherches, IRSST, R-316, Montréal, 217 p., www.irsst.qc.ca/fr/ _publicationirsst_859.html

Cru, D. (1995). Règles du métier, langue de métier : dimension symbolique au travail et démarche participative de prévention. Mémoire. École Pratique des Hautes Études. Paris.

Daniellou, F., Garrigou, A. (1995). L'ergonome, l'activité et la parole des travailleurs, In Paroles au travail, J. Boutet, p. 73-92. Éditions L'Harmattan, Paris.

Danis, C., Solar, C. (1998). Apprentissage et développement des adultes. Les Éditions Logiques, Montréal, $319 \mathrm{p}$.

Deforge, Y. (1991). La transmission et la préservation des savoir-faire et les enseignements techniques. In Chevallier, D. (1991). In Savoir-faire et pouvoir transmettre. Mission du Patrimoine 
ethnologique Collection Ethnologique de la France, Cahier 6, ed. D. Chevallier, p. 197-216. Éditions de la Maison des sciences de l'homme, Paris.

de Montmollin, M. (1997). Vocabulaire de l'Ergonomie, Éditions Octares, Toulouse, 245 p.

de Terssac, G. (1996). La genèse des savoir-faire. In Apprentissages formels et informels dans les organisations, Collection dossiers documentaires, p. 187-199. Édition ANACT, Lyon.

Denis, D., St-Vincent, M., Gonella, M., Couturier, F., Trudeau, R. (2007). Analyse des stratégies de manutention chez des éboueurs au Québec, Pistes de réflexions pour une formation. Études et recherches, IRSST, R-527, Montréal, 80 p., www.irsst.qc.ca/fr/_publicationirsst_100325.html Doray, P., Dubar, C. (2004). La formation en entreprise au Québec et en France. In Travail et société, Évolution et enjeux, ed. D.-G. Tremblay, p. 301-319. Presses de l'Université du Québec, Sainte-Foy.

Dubé, A., Mercure, D. (1997). Les entreprises et l'emploi. Les nouvelles formes de qualification du travail. Les Publications du Québec, Québec. 189 p.

Durand, M.J., Vézina, N., Baril, R., Loisel, P., Richard, M.-C., Ngomo, S. (2008). Étude exploratoire sur la marge de manœuvre de travailleurs pendant et après un programme de retour progressif au travail : définition et relation(s) avec le retour en emploi. Collection Études et Recherches, IRSST, Projet 099-477, Montréal, 65 p.

Everaere, C. (1999). Autonomie et collectif de travail. Collection Points de Repère, ANACT, p. 7-20.

Fournier, P.-S. (2003). L'aménagement de situations d'action sur le cours de vie professionnelle du camionneur : un apport à la démarche de conception d'une formation initiale en lien avec l'activité de travail. Thèse de doctorat. Université Laval. Québec. 345 p.

Garrigou, A., Peeters, S., Jackson, M., Sagory, P., Carballera, G. (2004). In Ergonomie, ed. P. Falzon, p. 497-514. Presses Universitaires de France, Paris.

Gaudart, C. (1996). Transformations de l'activité avec l'âge dans des tâches de montage automobile sur chaîne. Thèse de doctorat d'ergonomie. École Pratique des Hautes Études, Paris, $215 \mathrm{p}$.

Guérin, F., Laville, A., Daniellou, F., Duraffourg, J., Kerguelen, A. (2006). Comprendre le travail pour le transformer. La pratique de l'ergonomie. ( $1^{\text {re }}$ édition. $1991,2^{\mathrm{e}}$ édition, 1997) $3^{\mathrm{e}}$ édition. ANACT. $287 \mathrm{p}$.

Kerguelen, A. (2003). Actogram Kronos pour Windows, Éditions Octares, Toulouse.

Lachance, R. (2000). L'importance des mécanismes de régulation temporelle dans le travail des opératrices de métiers à fibres libérées relativement à l'automatisation des machines et au travail de nuit. PISTES, vol. 2, $\mathrm{n}^{\circ}$ 2, www.pistes.uqam.ca/v2n2/articles/v2n2a1.htm

Laflamme, R. (2002). La formation en entreprise : Nécessité ou contrainte ? Les Presses de l'Université Laval, Saint-Nicolas, 199 p.

Latash, M.L., Turvey, M.T. (1996). Dexterity and its development. With On Dexterity and its development by Nicholai A. Bernstein. LEA Lawrence Erlbaum Associates Inc., 460 p.

Le Boterf, G. (2006). Construire les compétences individuelles et collectives. Agir et réussir avec compétence. $4^{\mathrm{e}}$ édition mise à jour et complétée, Éditions d'Organisation, Paris, $271 \mathrm{p}$.

Leplat, J. (2005). Les automatismes dans l'activité : pour une réhabilitation et un bon usage. Activités, vol 2, n 2, www.activites.org/v2n2/html/leplat.html

Minet, F. (2005). Compétence : de la définition à l'utilisation. In Élaborer des référentiels de compétences, eds C. Jouvenot, M. Parlier, p. 332-362. Éditions ANACT, Lyon. 
Murray, G., Bélanger, J., Giles, A., Lapointe, P.-A. (2004). L'organisation de la production et du travail : vers un nouveau modèle ?, p. 29-35. Les Presses de l'Université Laval, Québec.

Organisation mondiale de la santé. Constitution de l'Organisation Mondiale de la Santé (1948), 20 p., /www.who.int/governance/eb/who_constitution_fr.pdf

Ouellet, S. (2006). Manuel de formation au dégraissage et au désossage de fesses de porc, Manuel préparé suite à une intervention réalisée dans le cadre d'un projet de doctorat. Université du Québec à Montréal, Montréal, 125 p.

Ouellet, S., Vézina N., Chartrand, J., Perrier P.-P., Malo J.-L. (2003). L'implantation de la rotation de postes : un exemple de démarche préalable. PISTES, vol. $5, n^{\circ} 2$, www.pistes.uqam.ca/v5n2/ articles/v5n2a14.htm

Ouellet, S., Vézina, N. (2001). Analyse des déterminants de la qualité de coupe du whizard : vers la concertation des actions et l'élaboration d'une formation. Comptes rendus du $36^{\mathrm{e}}$ Congrès de la Société d'ergonomie de langue française et $\mathrm{du} 32^{\mathrm{e}}$ Congrès de l'Association canadienne d'ergonomie - Les transformations du travail : enjeux pour l'ergonomie. Montréal, Québec, Canada. p. 1-6.

Ouellet, S. (2000). Étude ergonomique au poste de dégraisseur dans une usine de transformation du porc. Rapport, Département des sciences biologiques, Université du Québec à Montréal. Disponible au Centre de documentation de la Commission de la santé et de la sécurité du travail (CSST). Cote MO-022109. Montréal, 218 p.

Pastré, P. (2004). Recherches en didactique professionnelle. In Recherches en didactique professionnelle, eds R. Samurçay, P. Pastré, p. 4. Éditions Octarès, Toulouse.

Pelegrin, J. (1991). Les savoir-faire : une très longue histoire, Terrain, Revue d'ethnologie de l'Europe, $\mathrm{n}^{\circ} 16$, p. 1-13.

Rasse, P. (1991). La cité aromatique. Culture, techniques et savoir-faire dans les industries de la parfumerie grassoise. Terrain, revue d'ethnologie de l'Europe, $n^{\circ}$ 16, p. 1-27.

Reber, A. S. (1989). Implicit learning and tacit knowledge. Journal of Experimental Psychology, General, $n^{\circ} 118$, p. 219-235.

Richard, P. (2002). Analyse ergonomique et mesures biomécaniques dans un abattoir de porcs. PISTES, vol 4, $\mathrm{n}^{\circ}$ 1, www.pistes.uqam.ca/v4n1/articles/v4n1a3.htm

Rouilleault, H., Rochefort, T. (2005). Changer le travail... oui mais ensemble. ANACT, Lyon, p. 20-51.

Schmidt, R.A., Lee T.D., (2005). Motor control and learning. A behavioral emphasis. $4^{\mathrm{e}}$ edition, $\left(1^{\mathrm{re}}\right.$ édition $1982 ; 2^{\mathrm{e}} 1988 ; 3^{\mathrm{e}}$ édition, 1999), Human Kinetics, Champaign, $536 \mathrm{p}$.

Sperandio, J.-C. (1996). L'ergonomie face aux changements technologiques et organisationnels du travail humain. Éditions Octares, p. 11 à 25.

Stroobants, M. (1993). La mobilisation des compétences. In Savoir-faire et compétences au travail. Une sociologie de la fabrication des aptitudes, ed. M. Stroobants, p. 47-63. Éditions de l'Université de Bruxelles, Belgique.

Teiger, C. (1996). L'approche ergonomique : de travail humain à l'activité des hommes et des femmes au travail. In Apprentissages formels et informels dans les organisations, p. 109-125. Éditions ANACT, Lyon.

Teiger, C. (1993). Représentation du travail et travail de représentation. In Représentations pour l'action, eds A. Weill-Fassina, P. Rabardel, D. Dubois, p. 311-340. Éditions OCTARES, Toulouse. 
Teiger, C., Laville, A. (1989). Expression des travailleurs sur leurs conditions de travail. Rapport $\mathrm{n}^{\circ} 100$. Laboratoire d'ergonomie. CNAM, Paris.

Theureau, J. (1991). Cours d'action et savoir-faire. In Savoir-faire et pouvoir transmettre. Mission du Patrimoine ethnologique Collection Ethnologique de la France, Cahier 6, ed. D. Chevallier, p. 43-60. Éditions de la Maison des sciences de l'homme, Paris.

Vézina, N., Ouellet, S. (2002). Élaboration d'une méthode standardisée d'évaluation de la qualité de coupe des couteaux. Rapport déposé à la Commission de la santé et de la sécurité du travail (CSST). Montréal.

Vézina, N., Ouellet, S., Richard, P., Léveillée, M.-S. (2002). Procédure d'implantation de la formation à l'affilage des couteaux. Document déposé au Fonds québécois d'adaptation des entreprises agroalimentaires (FQAEA).

Vézina, N., (2001). La pratique de l'ergonomie face aux TMS : ouverture à l'interdisciplinarité. Comptes rendus du congrès SELF-ACE 2001, Les transformations du travail, enjeux pour l'ergonomie. www.ergonomie-self.org/actes/congres2001-1.html

Vézina, N., Prévost, J., Lajoie, A., Beauchamp, Y. (1999). Élaboration d'une formation à l'affilage des couteaux : le travail d'un collectif, travailleurs et ergonomes. PISTES, vol. 1, $\mathrm{n}^{\circ} 1$, www.pistes.uqam.ca/v1n1/articles/v1n1a3.htm

Vidal-Gomel, C. (2002). Systèmes d'instruments des opérateurs. Un point de vue pour analyser le rapport aux règles de sécurité. PISTES, vol. $4, \mathrm{n}^{\circ}$ 2, www.pistes.uqam.ca/v4n2/articles/ v4n2a2.htm

\section{NOTES}

1. In this article, the terms "know-how" and "skill" have the same meaning.

\section{ABSTRACTS}

Repetitive work is often seen as work that can be learned by simple observation of a colleague. This study aimed to describe the know-how and especially the know-how that can be used for one's protection, developed by six expert workers in a meat-cutting department. Individual and group interviews, on-site and video observations, and individual auto-confrontation (confronting participants with their own activity) were conducted. A typology of the know-how's knowledge base was developed and the existence of a hierarchy in the development of expertise was brought to light, including know-how called «efficient know-how ». This hierarchy highlights all the complexity of the work that should be considered in organizing training and presenting content. The ergonomic approach developed in this study and a theoretical framework resulting from practice have helped to uncover the wealth of knowledge that is mobilized in manual labor.

Le travail répétitif est souvent vu comme un travail qui peut s'apprendre par la simple observation d'un collègue. Cette étude a eu pour objectif de décrire les savoir-faire et en particulier ceux qui permettent de se protéger, qui sont développés par six travailleurs-experts 
d'un département de découpe de la viande. Des entretiens individuels et collectifs, des observations sur place et sur vidéos et des rencontres d'autoconfrontation ont été réalisés. Une typologie des savoirs à la base des savoir-faire a été élaborée et l'existence d'une hiérarchie dans la construction des savoir-faire a été dévoilée, notamment pour des savoir-faire appelés « savoirfaire efficients ». Cette hiérarchie fait ressortir toute la complexité du travail qui devrait être considérée dans l'organisation de la formation et la présentation du contenu. La démarche ergonomique développée dans cette étude ainsi qu'un cadre théorique issu de la pratique sur le terrain ont permis de mettre au jour la richesse des savoirs mobilisés dans le travail manuel.

El trabajo repetitivo está visto a menudo como un trabajo que puede aprenderse a traves de la simple observacion de un colega. Este trabajo intenta describir los saber-hacer y en particular aquellos que permiten protegerse, desarrollados por seis trabajadores expertos de un departamento de corte de carne. Se han realizado entrevistas individuales y colectivas, observaciones in situ y en base a videos, asi como encuentros de auto-confrontación. Una tipología de saberes fundacionales de los saber-hacer a sido abordada y la existencia de una jerarquía en la construcción de los saber-hacer ha sido develada, sobre todo para los saber-hacer llamados «saber-hacer eficientes ». Esta jerarquía hace resaltar toda la complejidad del trabajo que debería ser considerado en la organización de la formación y de la presentación del contenido. El enfoque ergonómico desarrollado en este estudio, asi como también un marco teórico inspirado en la práctica de campo, permitieron poner al día la riqueza de los saberes mobilizados en el trabajo manual.

INDEX

Mots-clés: ergonomie, troubles musculo-squelettiques, formation, savoir, savoir-faire

Palabras claves: ergonomía, lesiones músculo-esqueléticas, capacitación, saber, saber-hacer

Keywords: ergonomic, musculoskeletal disorders, training, knowledge, know how

\section{AUTHORS}

SYLVIE OUELLET

CINBIOSE, Université du Québec à Montréal, Montréal (Québec) ouellet.sylvie@uqam.ca

\section{NICOLE VÉZINA}

CINBIOSE, Université du Québec à Montréal, Montréal (Québec) vezina.nicole@uqam.ca 